\title{
Impact of pyruvic acid photolysis on acetaldehyde and peroxy radical formation in the boreal forest: theoretical calculations and model results
}

\author{
Philipp G. Eger ${ }^{1}$, Luc Vereecken ${ }^{2}$, Rolf Sander ${ }^{1}$, Jan Schuladen ${ }^{1}$, Nicolas Sobanski ${ }^{1}$, Horst Fischer ${ }^{1}$, Einar Karu ${ }^{1}$, \\ Jonathan Williams $^{1}$, Ville Vakkari ${ }^{3,4}$, Tuukka Petäjä ${ }^{5}$, Jos Lelieveld ${ }^{1}$, Andrea Pozzer ${ }^{1}$, and John N. Crowley ${ }^{1}$ \\ ${ }^{1}$ Atmospheric Chemistry Department, Max-Planck-Institute for Chemistry, 55128 Mainz, Germany \\ ${ }^{2}$ Institute for Energy and Climate Research: IEK-8, Forschungszentrum Juelich, 52425 Juelich, Germany \\ ${ }^{3}$ Atmospheric Composition Unit, Finnish Meteorological Institute, 00101 Helsinki, Finland \\ ${ }^{4}$ Atmospheric Chemistry Research Group, Chemical Resource Beneficiation, \\ North-West University, Potchefstroom, South Africa \\ ${ }^{5}$ Institute for Atmospheric and Earth System Research (INAR)/Physics, \\ Faculty of Science, University of Helsinki, Helsinki, Finland
}

Correspondence: John N. Crowley (john.crowley@mpic.de)

Received: 18 September 2020 - Discussion started: 20 October 2020

Revised: 1 September 2021 - Accepted: 7 September 2021 - Published: 28 September 2021

\begin{abstract}
Based on the first measurements of gas-phase pyruvic acid $\left(\mathrm{CH}_{3} \mathrm{C}(\mathrm{O}) \mathrm{C}(\mathrm{O}) \mathrm{OH}\right)$ in the boreal forest, we derive effective emission rates of pyruvic acid and compare them with monoterpene emission rates over the diel cycle. Using a data-constrained box model, we determine the impact of pyruvic acid photolysis on the formation of acetaldehyde $\left(\mathrm{CH}_{3} \mathrm{CHO}\right)$ and the peroxy radicals $\mathrm{CH}_{3} \mathrm{C}(\mathrm{O}) \mathrm{O}_{2}$ and $\mathrm{HO}_{2}$ during an autumn campaign in the boreal forest.

The results are dependent on the quantum yield $(\varphi)$ and mechanism of the photodissociation of pyruvic acid and the fate of a likely major product, methylhydroxy carbene $\left(\mathrm{CH}_{3} \mathrm{COH}\right)$. With the box model, we investigate two different scenarios in which we follow the present IUPAC (IUPAC Task Group on Atmospheric Chemical Kinetic Data Evaluation, 2021) recommendations with $\varphi=0.2$ (at 1 bar of air), and the main photolysis products $(60 \%)$ are acetaldehyde $+\mathrm{CO}_{2}$ with $35 \% \mathrm{C}-\mathrm{C}$ bond fission to form $\mathrm{HOCO}$ and $\mathrm{CH}_{3} \mathrm{CO}$ (scenario A). In the second scenario (B), the formation of vibrationally hot $\mathrm{CH}_{3} \mathrm{COH}$ (and $\mathrm{CO}_{2}$ ) represents the main dissociation pathway at longer wavelengths $(\sim 75 \%)$ with a $\sim 25 \%$ contribution from $\mathrm{C}-\mathrm{C}$ bond fission to form $\mathrm{HOCO}$ and $\mathrm{CH}_{3} \mathrm{CO}$ (at shorter wavelengths). In scenario 2 we vary $\varphi$ between 0.2 and 1 and, based on the results of our theoretical calculations, allow the thermalized $\mathrm{CH}_{3} \mathrm{COH}$
\end{abstract}

to react with $\mathrm{O}_{2}$ (forming peroxy radicals) and to undergo acid-catalysed isomerization to $\mathrm{CH}_{3} \mathrm{CHO}$.

When constraining the pyruvic acid to measured mixing ratios and independent of the model scenario, we find that the photolysis of pyruvic acid is the dominant source of $\mathrm{CH}_{3} \mathrm{CHO}$ with a contribution between $\sim 70 \%$ and $90 \%$ to the total production rate. We find that the photolysis of pyruvic acid is also a major source of the acetylperoxy radical, with contributions varying between $\sim 20 \%$ and $60 \%$ dependent on the choice of $\varphi$ and the products formed. $\mathrm{HO}_{2}$ production rates are also enhanced, mainly via the formation of $\mathrm{CH}_{3} \mathrm{O}_{2}$. The elevated production rates of $\mathrm{CH}_{3} \mathrm{C}(\mathrm{O}) \mathrm{O}_{2}$ and $\mathrm{HO}_{2}$ and concentration of $\mathrm{CH}_{3} \mathrm{CHO}$ result in significant increases in the modelled mixing ratios of $\mathrm{CH}_{3} \mathrm{C}(\mathrm{O}) \mathrm{OOH}$, $\mathrm{CH}_{3} \mathrm{OOH}, \mathrm{HCHO}$, and $\mathrm{H}_{2} \mathrm{O}_{2}$.

\section{Introduction}

Organic acids play a crucial role in tropospheric chemistry, impacting secondary organic aerosol formation, air quality, and climate (Kanakidou et al., 2005; Hallquist et al., 2009). Pyruvic acid $\left(\mathrm{CH}_{3} \mathrm{C}(\mathrm{O}) \mathrm{C}(\mathrm{O}) \mathrm{OH}\right)$, an organic acid that is central in plant metabolism as part of the Krebs cycle 


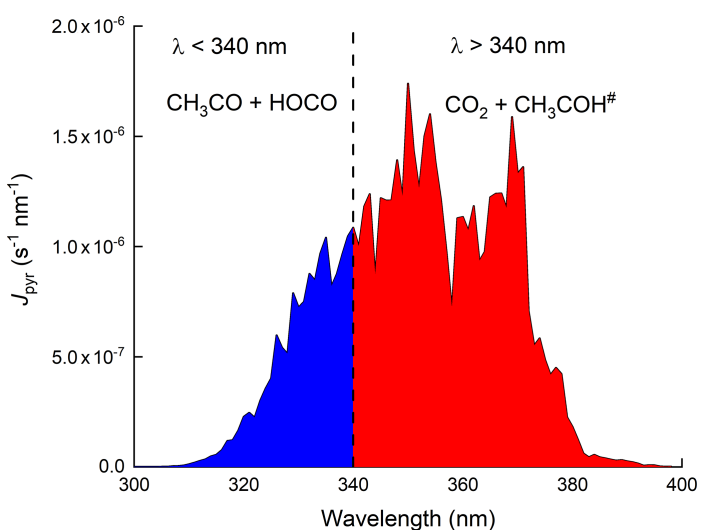

Figure 1. Wavelength-resolved photolysis rates $\left(J_{\text {pyr }}\right)$ for 13 September 2016 at solar noon. $J_{\text {pyr }}$ was calculated using a photolysis quantum yield of 1 and the absorption cross sections at $298 \mathrm{~K}$ preferred by IUPAC Task Group on Atmospheric Chemical Kinetic Data Evaluation (2021).

(Walker, 1962), is found in tropospheric air in the gas phase as well as in the aerosol phase, especially in the boundary layer over vegetated regions. Gas-phase mixing ratios ranging from a few to several hundred parts per trillion (pptv) have been reported in various locations around the world, including the tropical rainforest, boreal forest, rural areas with temperate forest, and regions influenced by urban outflow. A recent overview of existing measurements of gas-phase pyruvic acid is given by Eger et al. (2020).

A known source of pyruvic acid is the photo-oxidation of isoprene, via the ozonolysis of methyl vinyl ketone and subsequent hydrolysis of the Criegee intermediates (Jacob and Wofsy, 1988; Grosjean et al., 1993; Paulot et al., 2009). Further potential sources are the photolysis of methylglyoxal (Raber and Moortgat, 1995), the gas-phase photo-oxidation of aromatics in the presence of $\mathrm{NO}_{x}$ (Grosjean, 1984; Praplan et al., 2014), the aqueous-phase oxidation of methylglyoxal (Stefan and Bolton, 1999), and reactions taking place within biomass burning plumes (Andreae et al., 1987; Helas et al., 1992). In addition, pyruvic acid has been reported to be directly emitted from vegetation (Talbot et al., 1990; Jardine et al., 2010a, b; Eger et al., 2020). Compared to acetic acid, the presence of a second (non-acidic) carbonyl group imparts on pyruvic acid an absorption spectrum that extends from ultraviolet to visible wavelengths (see Fig. 1), and photolysis is a major sink of pyruvic acid in the boundary layer, with deposition and heterogeneous uptake to the aerosol phase also contributing to its removal. Photolysis of pyruvic acid in air results in a number of different radical and stable products; the major ones are expected to be acetaldehyde, $\mathrm{HO}_{2}$, and $\mathrm{CH}_{3} \mathrm{C}(\mathrm{O}) \mathrm{O}_{2}$ (more details are presented in Sect. 1.1). These products can have a significant impact on tropospheric chemistry, e.g. via the formation of peroxyacetyl nitrate (PAN), peracetic acid, and formaldehyde (HCHO).
Global models have recently revealed discrepancies between simulated and measured acetaldehyde concentrations (Millet et al., 2010; Wang et al., 2019; Wang et al., 2020). Wang et al. (2020) reported $\mathrm{CH}_{3} \mathrm{CHO}$ mixing ratios that were up to a factor of 10 higher than predicted by a global chemistry-transport model (EMAC) in the marine boundary layer around the Arabian Peninsula, implying missing sources of $\mathrm{CH}_{3} \mathrm{CHO}$ in remote and polluted regions. Wang et al. (2019) also found that models systematically underestimate $\mathrm{CH}_{3} \mathrm{CHO}$ compared to observations, implying a missing source of acetaldehyde in the remote troposphere. This finding was supported by the simultaneous measurement of peracetic acid (which is formed, for example, via the degradation of acetaldehyde in remote environments) with the organic aerosol source of $\mathrm{CH}_{3} \mathrm{CHO}$ also being insufficient to explain the results. Instead, Wang et al. (2019) suggested that $\mathrm{CH}_{3} \mathrm{CHO}$ arises from the degradation of gas-phase organic compounds. Pyruvic acid, among other organic acids in the gas and aerosol phase, might be one of the compounds that can be converted to acetaldehyde in the remote troposphere, and its integration into global models might contribute to resolve discrepancies, especially in forested regions.

Generally, field measurements as well as modelling and laboratory-based kinetic studies on pyruvic acid are limited, and its impact on atmospheric chemistry is still poorly understood. In this study we highlight the potential role of pyruvic acid in the boreal forest, one of the largest terrestrial biomes on Earth. For this, we use data from a measurement campaign in 2016 (IBAIRN, Influence of Biosphere-Atmosphere Interactions on the Reactive Nitrogen budget).

\section{The photolysis of pyruvic acid: quantum yields and products}

Because its reaction with $\mathrm{OH}$ is slow $\left(k_{\mathrm{OH}+\text { pyruvic acid }}=1.2 \times 10^{-13} \mathrm{~cm}^{3}\right.$ molecule $\mathrm{s}^{-1} \mathrm{~s}^{-1}$ at $298 \mathrm{~K}$; Mellouki and Mu, 2003), photolysis and dry deposition are the dominant loss terms for gas-phase pyruvic acid. Heterogeneous uptake to atmospheric aerosols is also calculated to be inefficient during the IBAIRN campaign in the boreal forest (see below), where particle surface area densities were of the order of $2 \times 10^{-7} \mathrm{~cm}^{2} \mathrm{~cm}^{-3}$, and the particles contained a large organic fraction (Liebmann et al., 2019) that is likely to reduce the uptake coefficient compared to that measured for pure aqueous particles $(\gamma=0.06$; Eugene et al. 2018).

The photodissociation of pyruvic acid at actinic wavelengths is not well understood. According to the most recent IUPAC Task Group on Atmospheric Chemical Kinetic Data Evaluation (2021) evaluation, which considers experimental data until 2017 , the three thermodynamically accessible photolysis channels are 


$$
\begin{aligned}
\mathrm{CH}_{3} \mathrm{C}(\mathrm{O}) \mathrm{C}(\mathrm{O}) \mathrm{OH} & +h v \rightarrow \mathrm{CH}_{3} \mathrm{CHO}+\mathrm{CO}_{2} \\
& \rightarrow \mathrm{CH}_{3} \mathrm{C}(\mathrm{O}) \mathrm{OH}+\mathrm{CO} \\
& \rightarrow \mathrm{CH}_{3} \mathrm{CO}+\mathrm{HOCO} .
\end{aligned}
$$

IUPAC recommends a photodissociation quantum yield $(\varphi)$ of 0.2 at 1 bar pressure (i.e. for boundary layer conditions), with branching ratios of $0.6,0.05$, and 0.35 for Reactions (R1), (R2), and (R3), respectively, which implicitly assumes that the initially formed carbene $\left(\mathrm{CH}_{3} \mathrm{COH}\right)$ immediately isomerizes to acetaldehyde. The radical products of Reaction (R3) $\left(\mathrm{CH}_{3} \mathrm{CO}\right.$ and $\left.\mathrm{HOCO}\right)$ react rapidly in air to form peroxy radicals (Reactions R4 and R5).

$$
\begin{aligned}
& \mathrm{CH}_{3} \mathrm{CO}+\mathrm{O}_{2}+M \rightarrow \mathrm{CH}_{3} \mathrm{C}(\mathrm{O}) \mathrm{O}_{2}+M \\
& \mathrm{HOCO}+\mathrm{O}_{2} \rightarrow \mathrm{HO}_{2}+\mathrm{CO}_{2}
\end{aligned}
$$

The formation of methylhydroxy carbene $\left(\mathrm{CH}_{3} \mathrm{COH}\right)$ as an intermediate in pyruvic acid photolysis has been postulated for many years (Vesley and Leermakers, 1964; Yamamoto and Back, 1985). Schreiner et al. (2011) observed isomerization of singlet $\mathrm{CH}_{3} \mathrm{COH}$ to acetaldehyde in an $\mathrm{Ar}$ matrix at $11 \mathrm{~K}$; their high-level theoretical analysis revealed high barriers for isomerization, where $\mathrm{H}$-atom tunnelling through the energy barrier led to a lifetime of about $1 \mathrm{~h}$ at $11 \mathrm{~K}$, which favoured the formation of acetaldehyde over that of vinyl alcohol. Only very recently has $\mathrm{CH}_{3} \mathrm{COH}$ been detected experimentally as a product of pyruvic acid photolysis in the gas-phase (Samanta et al., 2021) and its unimolecular isomerization to both $\mathrm{CH}_{3} \mathrm{CHO}$ and $\mathrm{CH}_{2}=\mathrm{CHOH}$ confirmed to be efficient at the experimental pressure of a few millibars (mbar) of helium. Indeed, Samanta et al. (2021) show that, at a photolysis wavelength of $351 \mathrm{~nm}$ (close to the maximum cross-section of pyruvic acid) formation of an energy-rich carbene $\left(\mathrm{CH}_{3} \mathrm{COH}^{\#}\right)$ and $\mathrm{CO}_{2}$ (Reaction R6) is essentially the only product channel operating. $\mathrm{CH}_{3} \mathrm{CHO}$ and $\mathrm{CH}_{2}=\mathrm{CHOH}$ were formed subsequently (at $\sim 2: 1$ ratio favouring $\mathrm{CH}_{3} \mathrm{CHO}$ ) in the unimolecular isomerization of $\mathrm{CH}_{3} \mathrm{COH}^{\#}$ (Reactions R7 and R8).

$$
\begin{array}{r}
\mathrm{CH}_{3} \mathrm{C}(\mathrm{O}) \mathrm{C}(\mathrm{O}) \mathrm{OH}+h v \rightarrow \mathrm{CH}_{3} \mathrm{COH}^{\#}+\mathrm{CO}_{2} \\
\mathrm{CH}_{3} \mathrm{COH}^{\#} \rightarrow \mathrm{CH}_{3} \mathrm{CHO} \\
\rightarrow \mathrm{CH}_{2}=\mathrm{CHOH}
\end{array}
$$

Samanta et al. (2021) suggest that, at ambient pressures, a significant fraction of the energized, nascent carbene will be deactivated by collisions with air (Reaction R9) and the thermalized carbene $\left(\mathrm{CH}_{3} \mathrm{COH}\right)$, which can no longer rapidly overcome the barriers to isomerization, may react with oxygen or water vapour (Reed Harris et al., 2016, 2017b; Eger et al., 2020; Samanta et al., 2021) (Reactions R10 and R11).

$$
\begin{aligned}
& \mathrm{CH}_{3} \mathrm{COH}^{\#}+M \rightarrow \mathrm{CH}_{3} \mathrm{COH}+M \\
& \mathrm{CH}_{3} \mathrm{COH}+\mathrm{O}_{2} \rightarrow \mathrm{CH}_{3} \mathrm{C}(\mathrm{O})+\mathrm{HO}_{2} \\
& \mathrm{CH}_{3} \mathrm{COH}+\mathrm{H}_{2} \mathrm{O} \rightarrow \mathrm{CH}_{3} \mathrm{CH}(\mathrm{OH})_{2}
\end{aligned}
$$

As summarized by IUPAC, there have been many experimental studies deriving primary photodissociation quantum yields and product yields following the photolysis of pyruvic acid. The studies which were carried out at atmospherically relevant wavelengths (i.e. within the $\sim 300-400 \mathrm{~nm}$ absorption band) are listed in Table S1 in the Supplement. The experiments were carried out at different pressures of various bath gases and at different wavelengths and at different concentrations of pyruvic acid, all of which appear to play a role in determining the products formed. Table $\mathrm{S} 1$ shows that $\mathrm{CO}_{2}$ is formed at a yield of close to $100 \%$, whereas the yield of $\mathrm{CH}_{3} \mathrm{CHO}$ is highly variable. $\mathrm{CH}_{2}=\mathrm{CHOH}$ has been detected both at a few torr of helium (Samanta et al., 2021) and at 1 bar of air (Calvert et al., 2011). Other end products observed during the photolysis of pyruvic acid in 1 bar of air include acetic acid (Calvert et al., 2011; Reed Harris et al., 2016, 2017b) and PAN (Grosjean, 1983; Berges and Warneck, 1992) when $\mathrm{NO}_{2}$ was present, which together provide evidence for the formation of the acetyl peroxy radical $\left(\mathrm{CH}_{3} \mathrm{C}(\mathrm{O}) \mathrm{O}_{2}\right)$ and thus $\mathrm{CH}_{3} \mathrm{CO}$, for example, in Reactions (R3) and (R4) when sunlight or solar-simulating light sources are used. Secondary products (resulting, for example, from the further reactions of $\mathrm{CH}_{3} \mathrm{CHO}$ ) such as $\mathrm{HCHO}$ and $\mathrm{CH}_{3} \mathrm{OH}$ have also been observed at pressures close to 1 bar (Grosjean, 1983; Calvert et al., 2011; Reed Harris et al., 2016; Reed Harris et al., 2017a). While the Norrish type 1 process $(\mathrm{C}-\mathrm{C}$ bond fission) forming $\mathrm{CH}_{3} \mathrm{CO}$ and $\mathrm{HOCO}$ appears to be unimportant at $351 \mathrm{~nm}$ (Samanta et al., 2021), it may be favoured at wavelengths $<340 \mathrm{~nm}$ (Chang et al., 2014). This is illustrated in Fig. 1 where we present the wavelength-resolved photolysis rate constants across the UV absorption spectrum of pyruvic acid (assuming an overall photolysis quantum yield of 1 , and absorption cross-sections recommended by IUPAC). The wavelength-resolved actinic flux was calculated for the IBAIRN measurement site on the 13 September 2016 using the Tropospheric Ultraviolet and Visible Radiation model (TUV; https://www.acom.ucar.edu/Models/ TUV/Interactive_TUV/, last access: 1 September 2020). Integration of the $J$ values at wavelengths $<340 \mathrm{~nm}$ indicates that (at local noon) $\approx 25 \%$ of pyruvic acid dissociation occurs at these shorter wavelengths.

\section{Methods}

The goal of this study is to evaluate the impact of pyruvic acid on acetaldehyde and radical formation rates in the boreal forest using a data-constrained, chemical box model. For this purpose we make use of experimental data from a field study, which was performed in the Finnish boreal forest at 
the Station for Measuring Ecosystem-Atmosphere Relations II (SMEAR II) in Hyytiälä $\left(61.846^{\circ} \mathrm{N}, 24.295^{\circ} \mathrm{E} ; 180 \mathrm{~m}\right.$ above sea level; see Hari and Kulmala, 2005), an area that is characterized by large emission rates of biogenics (mainly monoterpenes) and low- $\mathrm{NO}_{x}$ concentrations (Rinne et al., 2000; Williams et al., 2011; Aalto et al., 2015; Fischer et al., 2021).

The variability in the reported photodissociation quantum yield and product distributions (see discussion above) suggests that pyruvic acid photodissociation is not yet fully understood, In addition, the fate of the potentially dominant carbene product (Samanta et al., 2021) is unknown. Therefore, in order to better constrain the fate of $\mathrm{CH}_{3} \mathrm{COH}$ in the atmosphere, quantum chemical calculations were undertaken to characterize its likely atmospheric reactions, for which experimental data do not exist.

\subsection{The IBAIRN campaign}

The IBAIRN campaign took place in September 2016, during the summer-autumn transition, and was characterized by frequent temperature inversions near ground level during night-time (Liebmann et al., 2018a), which led to the accumulation of nocturnally emitted trace gases from vegetation. A detailed description of the campaign and the instruments deployed can be found elsewhere (Liebmann et al., 2018a; Eger et al., 2020). A summary (with details of detection limit, etc.) is provided in Table S2. Briefly, pyruvic acid was measured by a chemical ionization quadrupole mass spectrometer (Eger et al., 2020), the sum of monoterpenes (henceforth referred to as MT) was measured by a PTR-ToF-MS, and single MTs were monitored by a GC-AED (Liebmann et al., 2018a). Despite some discrepancies related to instrument location and inhomogeneity in terpene emissions within the forest, both instruments were in reasonably good agreement throughout the campaign. Since a high temporal resolution is preferable for our simulation, we have used the PTR-ToFMS dataset. $\mathrm{NO}$ and $\mathrm{NO}_{2}$ were measured by a chemiluminescence detector and a cavity ring-down spectrometer (Sobanski et al., 2016; Liebmann et al., 2018b), ozone was measured by optical absorption, and CO was measured by quantumcascade-laser absorption spectroscopy (Eger et al., 2020). Formic and acetic acid as well as methyl ethyl ketone (MEK) and methyl vinyl ketone (MVK) were taken from the continuous PTR-MS measurements at the site at heights between 42 and $336 \mathrm{~m}$. Photolysis rate coefficients were derived using actinic flux measurements from a spectral radiometer (METCON GmbH) (METCON GmbH) and evaluated cross sections and quantum yields (Burkholder et al., 2015). Mixing layer (MXL) heights were derived by combining in situ measurements made by a scanning Doppler lidar (Hellén et al., 2018) with results from the ECMWF ERA-Interim reanalysis (Dee et al., 2011), with a spatial resolution of $\sim 80 \mathrm{~km}$. Since the lidar was unable to resolve MXL heights $<60 \mathrm{~m}$ (as regularly experienced during nocturnal inversions), all values be- low this threshold have been set to $60 \mathrm{~m}$, representing an upper limit.

\subsection{Theoretical analysis of the fate of singlet methylhydroxy carbene, $\mathrm{CH}_{3} \mathrm{COH}$}

We investigated the reactions of $\mathrm{CH}_{3} \mathrm{COH}$ theoretically under atmospheric conditions, examining its unimolecular reactions and bimolecular reactions with $\mathrm{O}_{2}, \mathrm{H}_{2} \mathrm{O}$, and $\mathrm{HC}(\mathrm{O}) \mathrm{OH}$, where the latter is representative of carboxylic acids. The reaction with pyruvic acid itself is also briefly explored. The rovibrational characteristics and energetics of all critical points on the potential energy surface were characterized at the CCSD(T)/aug-cc-pVTZ//M06-2X-D3/aug-ccpVTZ level of theory with a wavenumber scaling factor of 0.971 (Zhao and Truhlar, 2008; Dunning, 1989; Purvis and Bartlett, 1982; Grimme et al., 2011; Database of Frequency Scale Factors for Electronic Model Chemistries (Version 4); Alecu et al., 2010). This method compares favourably with the more rigorous focal point analysis of Schreiner et al. (2011), with energy differences in the singlet state unimolecular chemistry of less than $0.7 \mathrm{kcal} \mathrm{mol}^{-1}$, indicating that the method is reliable for kinetic predictions under atmospheric temperatures. Where necessary, broken-symmetry SCF (selfconsistent field) calculations were used to describe singlet biradicals (Noodleman, 1981), and IRC (intrinsic reaction coordinate) calculations were used to verify the pathways. For reactants, products, and transition states, we exhaustively characterized all conformers; for complexes we only characterized those directly connecting to a transition state. All quantum chemical calculations were performed using the Gaussian-16 program suite (Frisch et al., 2016).

The quantum chemical data were then used to calculate high-pressure rate coefficients for reactions over a saddle point using multi-conformer transition state theory (MCTST) calculations (Vereecken and Peeters, 2003), under a rigid rotor harmonic oscillator approximation. Tunnelling corrections are performed assuming an asymmetric Eckart barrier (Eckart, 1930; Johnston and Heicklen, 1962). Most reactions have high energy barriers, and the presence of preand post-reaction complexes has a negligible influence on the reaction rate. For barrierless reactions, typically complexation reactions, we assume the reaction rate is close to the collision limit unless indicated otherwise.

\subsection{Box model}

We have used the CAABA/MECCA atmospheric chemistry box model to numerically simulate the impact of pyruvic acid photolysis on the formation of radicals and $\mathrm{CH}_{3} \mathrm{CHO}$ over the diel cycle during the IBAIRN campaign. Our study is based on model version 4.4.2, with updated reactions related to pyruvic acid in which two different scenarios were investigated (see Sect. 3.3) in order to examine the sensitivity of 
the model output to, for example, photolysis quantum yields and products.

The chemical mechanism used in this study contains $>600$ gas-phase species and $\sim 2000$ gas-phase reactions and photolysis steps. In addition to the basic ozone, $\mathrm{HO}_{x}$ and $\mathrm{NO}_{x}$ chemistry, the mechanism contains the detailed "Mainz Organic Mechanism" (MOM) for nonmethane hydrocarbons (NMHC), isoprene, terpenes, and aromatics. MOM is derived from a reduced version of the Master Chemical Mechanism (MCM). Full details about CAABA/MECCA and MOM are available in Sander et al. (2019). Photolysis reactions are calculated for a latitude of $62^{\circ} \mathrm{N}$. A complete reaction scheme and source of rate coefficients can be found in the data archive (see Data availability section).

Several parameters (temperature, pressure, relative humidity) and trace-gas concentrations (pyruvic acid, $\mathrm{O}_{3}, \mathrm{NO}$, $\mathrm{NO}_{2}$, PAN, CO, MTs, formic and acetic acid, methyl ethyl ketone (MEK), and methyl vinyl ketone, MVK) as well as the photolysis rate constants of various trace gases were constrained to values measured during the IBAIRN campaign.

Based on the GC-AED measurements, the MTs were split into $\alpha$-pinene (49\%), $\beta$-pinene (13\%), $\Delta$-carene $(27 \%)$, and camphene $(8 \%)$. Limonene is not included in the standard chemical mechanism of CAABA/MECCA, but as its contribution to the MTs during IBAIRN was only $3 \%$ it was treated as $\Delta$-carene (increasing the $\Delta$-carene contribution to $30 \%$ ).

The atmospheric methane mixing ratio was set to a constant value of $1.8 \mathrm{ppmv}$. Non-methane alkanes, the degradation of which represents $\sim 30 \%-45 \%$ of the acetaldehyde source globally (Millet et al., 2010), were constrained to $1000 \mathrm{pptv}$ of ethane, $250 \mathrm{pptv}$ of propane, and $150 \mathrm{pptv}$ of $n$ butane, as found in similar environments in Finland (Hakola et al., 2006; Hellén et al., 2015). The mixing ratio of PAN, which is generally the most abundant of the peroxy acetyl nitrates (PNs), was calculated from a measurement of the sum of peroxy nitrates, whereby $[\mathrm{PAN}]=0.9 \times \Sigma[\mathrm{PNs}]$ (estimation based on observations by, for example, Shepson et al., 1992b; Roberts et al., 2004; Roiger et al., 2011). The modelgenerated, averaged $\mathrm{OH}$ concentration through the diel cycle was in good agreement (within $\sim 20 \%$ ) with that calculated from the correlation of ground-level $\mathrm{OH}$ measurements with UVB radiation intensity at the Hyytiälä site (with $[\mathrm{OH}]=5.62 \times 10^{5}[\mathrm{UVB}]^{0.62}$ molecule $\mathrm{cm}^{-3}$ when UVB is in units of $\mathrm{W} \mathrm{m}^{-2}$; Petäjä et al., 2009; Hellén et al., 2018) but showed more variability resulting from changes in $\mathrm{NO}$ mixing ratios and the conversion of $\mathrm{HO}_{2}$ to $\mathrm{OH}$.

\section{Results and discussion}

In the following, we analyse in situ measurements of pyruvic acid to derive emission rates, present the results of the theoretical calculations of the fate of $\mathrm{CH}_{3} \mathrm{OH}$, and discuss the box-model output for the IBAIRN campaign with a focus on pyruvic acid emission rates and its impact on acetaldehyde and radical chemistry in the boundary layer of the boreal forest.

\subsection{Pyruvic acid emission rate relative to monoterpenes during IBAIRN}

In order to derive the pyruvic acid emission rate $\left(E_{\text {pyr }}\right)$ during IBAIRN, we assume that only photolysis and dry deposition contribute significantly to its overall loss rate and that pyruvic acid is in steady state. The latter assumption is reasonable as its mean lifetime was $(2 \pm 0.5) \mathrm{h}$. Due to a homogeneous fetch at the measurement site, we can neglect transport processes, and $E_{\text {pyr }}$ is defined by Eq. (1), where $[\mathrm{pyr}]_{\mathrm{ss}}$ is the measured mixing ratio, $J_{\mathrm{pyr}}$ is the photolysis rate constant of pyruvic acid, $k_{\text {dep }}$ is the first-order loss rate constant for its dry deposition, and $h_{\mathrm{MXL}}$ is the well-mixed boundary layer height.

$E_{\mathrm{pyr}}=[\mathrm{pyr}]_{\mathrm{ss}}\left(J_{\mathrm{pyr}}+k_{\mathrm{dep}}\right) h_{\mathrm{MXL}}$

$E_{\text {pyr }}$ is effectively an emission rate normalized to the MXL height $\left(h_{\mathrm{MXL}}\right)$. As the photolysis is a substantial fraction of the overall losses of $\mathrm{CH}_{3} \mathrm{C}(\mathrm{O}) \mathrm{C}(\mathrm{O}) \mathrm{OH}$, the choice of quantum yield $\varphi$ directly impacts the calculated emission rate.

The deposition rate of pyruvic acid was calculated from $k_{\mathrm{dep}}=v_{\mathrm{dep}} h_{\mathrm{MXL}}^{-1}$ during the day and $k_{\mathrm{dep}}=2 v_{\mathrm{dep}} h_{\mathrm{MXL}}^{-1}$ during the night (Shepson et al., 1992a), with the transition following the diel variation in the mixing layer height $h_{\mathrm{MXL}}$ (see Fig. S1 in the Supplement). Further, as pyruvic acid and $\mathrm{H}_{2} \mathrm{O}_{2}$ have similar solubilities, we assumed that their deposition velocities are equal, so that $v_{\text {dep }}=8.4 \mathrm{~cm} \mathrm{~s}^{-1}$ during the day and $v_{\text {dep }}=0.8 \mathrm{cms}^{-1}$ during the night, as derived by Crowley et al. (2018) for the same site. This resulted in a minimum dry-deposition loss rate constant of $k_{\text {dep }}=0.9 \times 10^{-4} \mathrm{~s}^{-1}$ during the day and a maximum of $k_{\mathrm{dep}}=1.8 \times 10^{-4} \mathrm{~s}^{-1}$ during the night.

The same calculation is performed for the MTs $\left(E_{\mathrm{MT}}\right)$ over the same period (and thus for the same MXL height). We note that $h_{\mathrm{MXL}}$ controls not only the value of $k_{\mathrm{dep}}$, but also directly affects the mixing ratios of both MTs and pyruvic acid for a given emission rate. The relative emission rate $\left(E_{\mathrm{pyr}} / E_{\mathrm{MT}}\right)$ can be calculated from Eq. (2), where terms in square brackets are concentrations.

$\frac{E_{\mathrm{pyr}}}{E_{\mathrm{MT}}}=\frac{[\mathrm{pyr}]_{\mathrm{ss}}\left(J_{\mathrm{pyr}}+k_{\mathrm{dep}}\right)}{[\mathrm{MT}]_{\mathrm{ss}}\left(k_{\mathrm{OH}}[\mathrm{OH}]+k_{\mathrm{NO}_{3}}\left[\mathrm{NO}_{3}\right]+k_{\mathrm{O}_{3}}\left[\mathrm{O}_{3}\right]\right)}$

In the denominator, $k_{\mathrm{OH}}, k_{\mathrm{NO}_{3}}$, and $k_{\mathrm{O}_{3}}$ are rate coefficients for reaction of MTs with $\mathrm{OH}, \mathrm{NO}_{3}$, and $\mathrm{O}_{3}$, respectively. As we do not have $\mathrm{GC}$ data at high time resolution, an effective rate coefficient for loss of the monoterpenes was derived from the mean MT composition as measured by GCAED (49\% $\alpha$-pinene, $13 \% \beta$-pinene, $27 \%$ carene (sum of 2 -carene and 3 -carene), $3 \% d$-limonene, and $8 \%$ camphene) and the corresponding rate coefficients (Perring et al., 2013; 


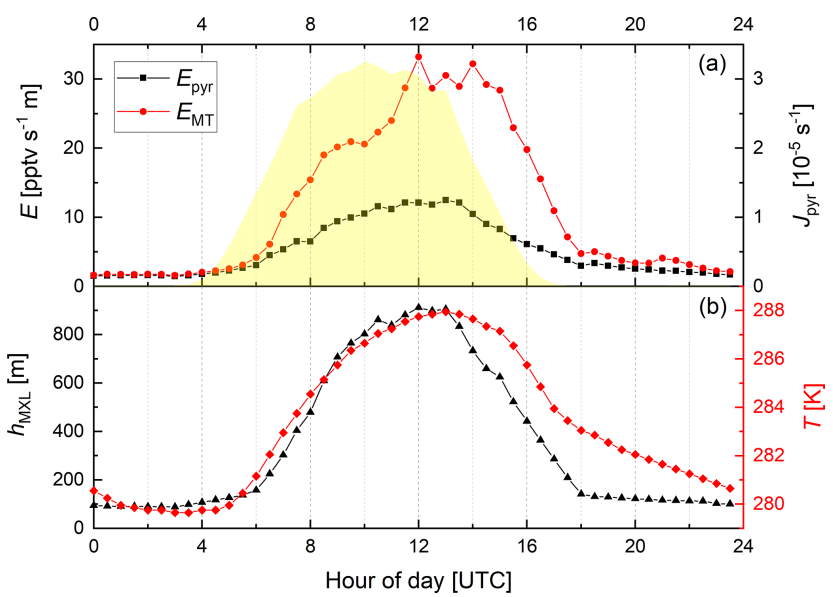

Figure 2. Diel variation of the (MXL height-corrected) emission rates of pyruvic acid ( $E_{\mathrm{pyr}}$, scenario B) and monoterpenes $\left(E_{\mathrm{MT}}\right)$ along with $J_{\text {pyr }}$ (yellow shaded), $T$, and $h_{\mathrm{MXL}}$ for the IBAIRN campaign.

Gaona-Colman et al., 2017; IUPAC Task Group on Atmospheric Chemical Kinetic Data Evaluation, 2021). This will introduce significant uncertainty (factor of $\sim 2$ ) into the calculation of the MT emission rates. Further uncertainty arises from the measurement of pyruvic acid, $\Sigma \mathrm{MT}, \mathrm{OH}, \mathrm{O}_{3}, \mathrm{NO}_{3}$, $h_{\mathrm{MXL}}$, and $J_{\mathrm{pyr}}$. In particular, the results are very sensitive to the deposition velocity $\left(v_{\text {dep }}\right)$ of pyruvic acid, which is an estimate based on the deposition velocity of $\mathrm{H}_{2} \mathrm{O}_{2}$, which itself has an uncertainty of $\sim 90 \%$ (Fischer et al., 2019). Further, our calculations are based on the assumption that the sources of pyruvic acid and MT are evenly distributed, and measurements made at $\sim 8.5 \mathrm{~m}$ above the ground are representative of the entire boundary layer (i.e. that the boundary layer is wellmixed, including the very shallow boundary layer at night). A gradient in pyruvic acid mixing ratios at night cannot be ruled out, which would impact on our results. We estimate that the emission ratio $\left(E_{\mathrm{pyr}} / E_{\mathrm{MT}}\right)$ in Eq. (2) is associated with an overall uncertainty of a factor of $\sim 3$ notwithstanding the use of different quantum yields (and thus $J$ values) for pyruvic acid photolysis.

A time series of pyruvic acid and MT mixing ratios along with the MXL height $\left(h_{\mathrm{MXL}}\right)$ derived from a lidar measurement and from the ERA-Interim reanalysis is shown in Fig. S2. Whereas both MXL height datasets agree very well during the night when the MXL is shallow (usually $<100 \mathrm{~m}$ ), the lidar data are on average a factor of $\sim 2$ lower during the day and characterized by a much higher variability. For the derivation of the diel profile of $h_{\mathrm{MXL}}$ (Fig. S1), we took an average of both datasets. The diel variation displayed in Fig. S2, with the highest MT mixing ratios at night, is characteristic of this boreal forest site and has been observed in earlier studies (Hellén et al., 2018).

In the following, we focus on the mean, diel profiles of $E_{\mathrm{pyr}}, E_{\mathrm{MT}}, J_{\mathrm{pyr}}, T$, and $h_{\mathrm{MXL}}$ for the IBAIRN campaign, which are presented in Fig. 2. A plot showing the variability of the MT and pyruvic acid mixing ratios over the same period was previously reported (see Fig. 3 of Eger et al., 2020).

During September, the emission rate of pyruvic acid $\left(E_{\mathrm{pyr}}\right)$ reaches its maximum a few hours after solar noon when the temperature peaks, similar to $E_{\mathrm{MT}}$. However, the amplitude of the day-to-night difference in $E_{\mathrm{pyr}}$ is a factor of $\sim 3$ smaller than observed for $E_{\mathrm{MT}}$. This could indicate that pyruvic acid emissions are less temperature-dependent than MT emissions (see below) and that other environmental factors might additionally play a role at this time of year.

The emission rates of the MTs derived as described above show a large day-night variation with values a factor of $\sim 20$ larger around noontime compared to midnight. This is significantly larger than the expected variation (factor of 2-3) based on the average noon-to-midnight temperature difference of $10 \mathrm{~K}$ and the parameterization of Guenther et al. (1993), whereby $E_{\mathrm{MT}} \propto \exp (\beta(T-297 \mathrm{~K}))$ with $\beta=0.1 \mathrm{~K}^{-1}$ (which is in line in with the empirical value of $\beta=0.12 \mathrm{~K}^{-1}$ that was derived for this site in September by Hellén et al., 2018). One potential reason for this discrepancy may be emissions in autumn from fresh leaf litter that significantly contribute to the observed mixing ratios (Hellén et al., 2018) although the assumption of evenly distributed sources and a well-mixed boundary layer is not necessarily valid during the night, especially during strong temperature inversions.

Figure $\mathrm{S} 3$ shows that the daytime emission of pyruvic acid relative to $\mathrm{MT}\left(E_{\mathrm{pyr}} / E_{\mathrm{MT}}\right)$ varies by a factor of $\sim 2$, depending on the chosen scenario, whereas the nighttime emission ratio is only dependent on the deposition velocity of pyruvic acid. For further analysis we adopt a quantum yield of 0.2 , as presently preferred by IUPAC. On average, $\left(E_{\mathrm{pyr}} / E_{\mathrm{MT}}\right)$ $\sim 0.6$, with a minimum value of $\sim 0.3$ in the evening and a maximum value of $\sim 1$ in the early morning, indicating elevated pyruvic acid emissions relative to MT at night. To derive a $T$-dependent expression from the diurnal profile of the emission factor, we fit an exponential function to the plot of temperature versus $E_{\mathrm{pyr}} / E_{\mathrm{MT}}$ (Fig. S4), yielding

$E_{\mathrm{pyr}}=\left[0.28+3.17 \cdot \exp \left(\frac{273-T}{4.24}\right)\right] \cdot$ EMT.

We note that (like the values of $E_{\mathrm{pyr}}$ ) the temperature dependence derived is strongly influenced by the diel variation of the MXL height and thus carries significant uncertainty and may not be transferable to other locations or even times of the year.

As our measurements of pyruvic acid are the first to have been made in the boreal forest, we cannot compare our relative emission ratio $\left(E_{\mathrm{pyr}} / E_{\mathrm{MT}}\right)$ with previous measurements in a similar environment. Instead, where possible, we derive the emission ratio from measurements of MTs, isoprene, and pyruvic acid in warmer climates.

Jardine et al. (2010b) performed measurements in an enclosed (glass dome) tropical forest biome at Biosphere 2 in 
Table 1. Emission rate of pyruvic acid $\left(E_{\mathbf{p y r}}\right)$ relative to isoprene $\left(E_{\mathbf{i s o}}\right)$ and $\mathrm{MT}\left(E_{\mathbf{M T}}\right)$.

\begin{tabular}{lllrr}
\hline Reference & Location & Plant species & $\left(E_{\mathrm{pyr}} / E_{\mathrm{iso}}\right)$ & $\left(E_{\mathrm{pyr}} / E_{\mathrm{MT}}\right)$ \\
\hline This study & Hyytiälä, Finland & Boreal forest & $\sim 20$ & 0.62 \\
Talbot et al. (1990) & Manaus, Brazil & Tropical forest & 0.003 & - \\
Jardine et al. (2010b) & Biosphere 2, Arizona, US & Tropical biome & 0.17 & 4 \\
Jardine et al. (2010b) & Biosphere 2, Arizona, US & Mango tree & 0.05 & 1.7 \\
Jardine et al. (2010a) & Biosphere 2, Arizona, US & Creosote bush & 0.05 & 0.07 \\
\hline
\end{tabular}

Arizona, US, where they found maximum mixing ratios of $120 \mathrm{ppbv}$ isoprene, $6 \mathrm{ppbv}$ MTs, and $15 \mathrm{ppbv}$ pyruvic acid. As the glass dome absorbed actinic wavelengths and prevented active photochemistry, the chemical loss processes for pyruvic acid, isoprene, and MT (including photolysis and reactions with $\mathrm{OH}, \mathrm{O}_{3}$, and $\mathrm{NO}_{3}$ ) are negligible. Initially disregarding the deposition of isoprene and MT, we derive lower limits of $\left(E_{\mathrm{pyr}} / E_{\mathrm{iso}}\right) \sim 0.17$ and $\left(E_{\mathrm{pyr}} / E_{\mathrm{MT}}\right)$ $\sim 4$ (see Table 1). However, due to the presence of large concentrations of isoprene-consuming microbes in the soil of Biosphere 2, the isoprene loss rate via deposition may be enhanced, which will decrease the effective emission ratio $\left(E_{\mathrm{pyr}} / E_{\mathrm{iso}}\right)$. In addition, branch enclosure studies were performed on a Mangifera indica (mango) tree within Biosphere 2, yielding mean fluxes (in $\mathrm{nmol} \mathrm{m}^{-2} \mathrm{~s}^{-1}$ ) of 3.2 for isoprene, 0.09 for MT, and 0.15 for pyruvic acid. Pyruvic acid emissions peaked during the day when temperature and photosynthetically active radiation (PAR) were highest and correlated very well with isoprene emissions and (to a certain extent) with MT emissions. Assuming that a mango tree is representative of the tropical vegetation, we derive an emission ratio of $\left(E_{\mathrm{pyr}} / E_{\text {iso }} \sim 0.05\right.$ and $\left(E_{\mathrm{pyr}} / E_{\mathrm{MT}}\right) \sim 1.7$ (see Table 1), which is consistent with our estimations for the IBAIRN campaign. However, given that Talbot et al. (1990) observed great variability in pyruvic acid emission fluxes among five different tree species during measurements in the tropical Ducke Forest Reserve close to Manaus, Brazil, this agreement may, to some extent, be coincidental. Talbot et al. (1990) also reported a mean emission flux (derived from enclosure experiments) relative to isoprene of ( $\left.E_{\mathrm{pyr}} / E_{\mathrm{iso}}\right)$ $\sim 0.003$, which is about 1 order of magnitude smaller than in the study of Jardine et al. (2010b). In a further branch enclosure study by Jardine et al. (2010a) emissions from a creosote bush (Larrea divaricata), which is typically found in US drylands, were investigated. Average noontime branch emission rates (in $\mu \mathrm{g} \mathrm{Cgdw}{ }^{-1} \mathrm{~h}^{-1}$ ) of $7.5,10.4$, and 0.2 for isoprene, MT, and pyruvic acid resulted in relative emission ratios of $\left(E_{\mathrm{pyr}} / E_{\mathrm{iso}}\right) \sim 0.05$ and $\left(E_{\mathrm{pyr}} / E_{\mathrm{MT}}\right) \sim 0.07$ for this mixed isoprene-MT-emitting species.

The comparison with the few datasets available in the literature indicates that the variability of the emission factors $\left(E_{\mathrm{pyr}} / E_{\mathrm{MT}}\right)$ and $\left(E_{\mathrm{pyr}} / E_{\mathrm{iso}}\right)$ among different plant species and different environments is large. In addition, a lack of pyruvic acid measurements over different seasons in the bo- real forest means that we cannot exclude that the value we derive is biased by emissions (e.g. from ground-level, decaying plant litter in September) that are particular to this season and environment. The emission rates we derive are therefore relevant for the autumnal boreal forest but require validation before being extended to other regions and seasons with confidence.

\subsection{Theoretical calculations on the fate of $\mathrm{CH}_{3} \mathrm{COH}$}

Singlet methylhydroxy carbene, $\mathrm{CH}_{3} \mathrm{COH}$, is best characterized as having an $\mathrm{sp}^{2}$-hybridized central carbon, bearing an in-plane lone pair in an $\mathrm{sp}^{2}$ orbital and an empty p orbital perpendicular to the $\mathrm{CCO}$ plane. The lone pairs of the hydroxy $\mathrm{O}$ atom back-donate into the empty p orbital, such that the most favourable geometry has the hydroxy-H atom in the $\mathrm{CCO}$ plane. The orientation of the terminal $\mathrm{OH}$ group has a large impact on the energy, with $3 \mathrm{kcal} \mathrm{mol}^{-1}$ energy difference between the syn- and anti-conformers. Due to the interaction between the hydroxy $\mathrm{O}$ atom and the carbene functionality, internal rotation of the $\mathrm{OH}$ group has a very high barrier, $24 \mathrm{kcal} \mathrm{mol}^{-1}$. Concomitantly, syn/anti-interconversion is very slow, with predicted rate coefficients at $300 \mathrm{~K}$ of less than $10^{-2} \mathrm{~s}^{-1}$. Under atmospheric conditions, thermalized syn- and anti- $\mathrm{CH}_{3} \mathrm{COH}$ are thus best considered as separate species, with possibly distinct chemistry. No information is available on the relative yield of these conformers from pyruvic acid photolysis.

\subsubsection{Unimolecular reactions of $\mathrm{CH}_{3} \mathrm{COH}$}

Both syn- and anti- $\mathrm{CH}_{3} \mathrm{COH}$ can isomerize to vinyl alcohol over high barriers $\geq 24 \mathrm{kcal} \mathrm{mol}^{-1}$ (see Fig. 3). Anti$\mathrm{CH}_{3} \mathrm{COH}$ has an additional pathway for isomerization to acetaldehyde, with a barrier of $23 \mathrm{kcal} \mathrm{mol}^{-1}$. Due to these high barriers, the thermal rate of isomerization is comparatively slow, with a $300 \mathrm{~K}$ rate coefficient of $\leq 4 \times 10^{-4} \mathrm{~s}^{-1}$ (see Table 2). As already discussed by Schreiner et al. (2011), formation of $\mathrm{CH}_{3} \mathrm{CHO}$ from anti- $\mathrm{CH}_{3} \mathrm{COH}$ is most favourable at low temperatures, owing to a thinner energy barrier and hence faster tunnelling. At temperatures above $260 \mathrm{~K}$, we find that formation of $\mathrm{CH}_{2}=\mathrm{CHOH}$ from anti- $\mathrm{CH}_{3} \mathrm{COH}$ becomes dominant, with a $\sim 3.5: 1$ ratio of $\mathrm{CH}_{2}=\mathrm{CHOH}$ to $\mathrm{CH}_{3} \mathrm{CHO}$ at room temperature. 
Table 2. Theory-predicted high-pressure rate coefficients for reaction of singlet $\mathrm{CH}_{3} \mathrm{COH}$.

\begin{tabular}{|c|c|c|c|c|c|}
\hline Reactants & Products & $k(298 \mathrm{~K})$ & $A$ & $n$ & $E_{\mathrm{a}}$ \\
\hline syn- $\mathrm{CH}_{3} \mathrm{COH}+\mathrm{O}_{2}$ & $\mathrm{CH}_{3} \mathrm{C}(\mathrm{OH}) \mathrm{OO}^{\bullet}$ & $2.2 \times 10^{-20}$ & $5.74 \times 10^{-22}$ & 3.05 & 4092 \\
\hline anti- $\mathrm{CH}_{3} \mathrm{COH}+\mathrm{O}_{2}$ & $\mathrm{CH}_{3} \mathrm{C}(\mathrm{OH}) \mathrm{OO}^{\bullet}$ & $6.6 \times 10^{-21}$ & $1.71 \times 10^{-22}$ & 2.97 & 3960 \\
\hline syn- $\mathrm{CH}_{3} \mathrm{COH}+\mathrm{H}_{2} \mathrm{O}$ & $\mathrm{CH}_{3} \mathrm{CH}(\mathrm{OH})_{2}$ & $1.9 \times 10^{-20}$ & $1.57 \times 10^{-55}$ & 13.56 & -1049 \\
\hline anti- $\mathrm{CH}_{3} \mathrm{COH}+\mathrm{H}_{2} \mathrm{O}$ & $\mathrm{CH}_{3} \mathrm{CH}(\mathrm{OH})_{2}$ & $5.7 \times 10^{-21}$ & $1.09 \times 10^{-61}$ & 15.61 & -1443 \\
\hline \multirow[t]{2}{*}{ syn- $\mathrm{CH}_{3} \mathrm{COH}$} & anti- $\mathrm{CH}_{3} \mathrm{COH}$ & $8.9 \times 10^{-3}$ & $7.86 \times 10^{-20}$ & 10.77 & 6598 \\
\hline & $\mathrm{CH}_{2}=\mathrm{CHOH}$ & $1.9 \times 10^{-4}$ & $3.62 \times 10^{-91}$ & 34.20 & -1444 \\
\hline \multirow[t]{3}{*}{ anti- $\mathrm{CH}_{3} \mathrm{COH}$} & syn- $\mathrm{CH}_{3} \mathrm{COH}$ & $2.8 \times 10^{-5}$ & $6.55 \times 10^{-20}$ & 10.71 & 8137 \\
\hline & $\mathrm{CH}_{2}=\mathrm{CHOH}$ & $9.2 \times 10^{-5}$ & $2.02 \times 10^{-14}$ & 40.40 & -6660 \\
\hline & $\mathrm{CH}_{3} \mathrm{C}(=\mathrm{O}) \mathrm{H}$ & $3.4 \times 10^{-4}$ & $1.26 \times 10^{-81}$ & 30.96 & -563 \\
\hline $\mathrm{CH}_{2}=\mathrm{CHOH}+\mathrm{HCOOH}$ & $\mathrm{CH}_{3} \mathrm{C}(=\mathrm{O}) \mathrm{H}+\mathrm{HCOOH}$ & $2.9 \times 10^{-18}$ & $1.82 \times 10^{-76}$ & 19.88 & -6192 \\
\hline $\mathrm{CH}_{3} \mathrm{C}(=\mathrm{O}) \mathrm{H}+\mathrm{HCOOH}$ & $\mathrm{CH}_{2}=\mathrm{CHOH}+\mathrm{HCOOH}$ & $8.1 \times 10^{-27}$ & $1.09 \times 10^{-78}$ & 20.59 & -633 \\
\hline
\end{tabular}

Calculations were performed at the CCSD(T)//M06-2X-D3 with MC-TST level of theory. Rate coefficients are given at $298 \mathrm{~K}_{\left(\mathrm{s}^{-1}\right.}$ or $\mathrm{cm}^{3}$ molecule $\left.{ }^{-1} \mathrm{~s}^{-1}\right)$. Temperature-dependent rate coefficients can be calculated using the parameters of a Kooij expression $k(200-450 \mathrm{~K})=A \cdot(T / K)^{n} \cdot \exp \left(-E_{\mathrm{a}} / T\right)$ with $A$ given per second $\left(\mathrm{s}^{-1}\right)$ or cubic centimetres per molecule per second $\left(\mathrm{cm}^{3}\right.$ molecule $\left.^{-1} \mathrm{~s}^{-1}\right)$ and $E_{\mathrm{a}}$ in kelvin $(\mathrm{K})$.

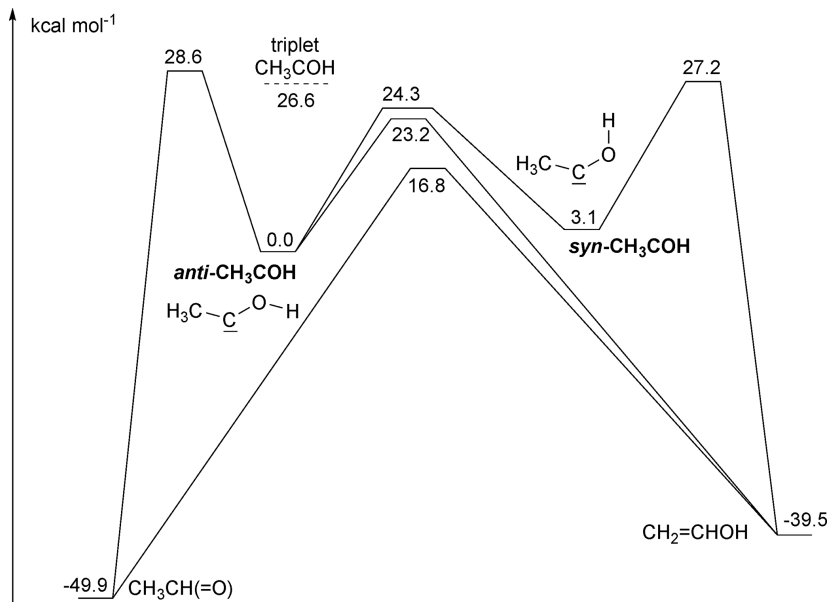

Figure 3. Zero point energy (ZPE)-corrected potential energy surface for unimolecular reactions of singlet $\mathrm{CH}_{3} \mathrm{COH}$ at the CCSD(T)//M06-2X-D3 level of theory.

Given the low predicted thermal rate coefficients, it seems unlikely that the experimentally observed acetaldehyde and vinyl alcohol in pyruvic acid photolysis are formed from isomerization of thermalized $\mathrm{CH}_{3} \mathrm{COH}$. The energy distribution of energized, nascent carbenes would be rather broad as the available energy upon pyruvic acid photodissociation is distributed over all fragments and their relative motion, and the isomerization yield would then be pressuredependent. The $\mathrm{CH}_{3} \mathrm{CHO}$ and $\mathrm{CH}_{2}=\mathrm{CH}_{2} \mathrm{OH}$ isomers formed would have enough energy to undergo keto-enol tautomerization, but given the high barrier exceeding $55 \mathrm{kcal} \mathrm{mol}^{-1}$, it is

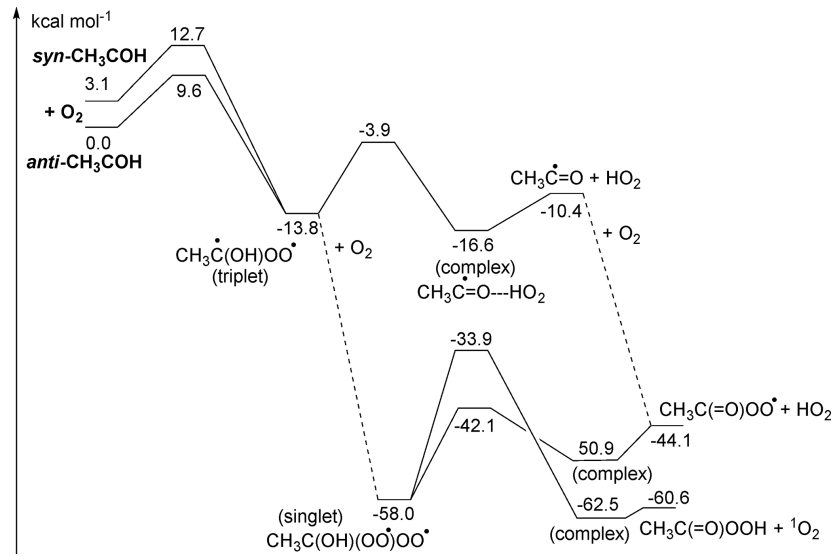

Figure 4. ZPE-corrected potential energy surface for reaction of singlet $\mathrm{CH}_{3} \mathrm{COH}$ with $\mathrm{O}_{2}$ at the $\mathrm{CCSD}(\mathrm{T}) / / \mathrm{M} 06-2 \mathrm{X}-\mathrm{D} 3$ level of theory.

more probable they will instead be stabilized by collisional energy loss.

\subsubsection{Reaction of $\mathrm{CH}_{3} \mathrm{COH}$ with $\mathrm{O}_{2}$}

Under atmospheric conditions, the reaction with $\mathrm{O}_{2}$ is potentially an important loss process for $\mathrm{CH}_{3} \mathrm{COH}$ (Reed Harris et al., 2016, 2017a; Eger et al., 2020). The potential energy surface is shown in Fig. 4. Contrary to radicals, which react with $\mathrm{O}_{2}$ by (near-)barrierless radical recombination, the singlet $\mathrm{CH}_{3} \mathrm{COH}$ carbene does not have an unpaired electron and the reaction proceeds mostly by association of its outof-plane empty p orbital with a lone electron pair in $\mathrm{O}_{2}$, re- 
quiring orbital rearrangement to a triplet $\mathrm{C}^{\bullet} \mathrm{OO}^{\bullet}$ moiety with a $\mathrm{sp}^{3}$-hybridized central carbon. This unfavourable process has high barriers, $>9 \mathrm{kcal} \mathrm{mol}^{-1}$, and concomitantly low rate coefficients, $k(298 \mathrm{~K}) \sim 10^{-20} \mathrm{~cm}^{3}$ molecule ${ }^{-1} \mathrm{~s}^{-1}$ (see Table 2). The rate coefficient is however highly uncertain, owing to an uncertainty $\left(\sim 1\right.$ to $\left.2 \mathrm{kcal} \mathrm{mol}^{-1}\right)$ on the barrier height.

The decomposition of the $\mathrm{CH}_{3} \mathrm{C}^{\bullet}(\mathrm{OH}) \mathrm{OO}^{\bullet}$ triplet diradical intermediate, forming $\mathrm{CH}_{3} \mathrm{C}^{\circ}=\mathrm{O}+\mathrm{HO}_{2}$, is reminiscent of the chemistry of $\alpha-\mathrm{OH}$ alkyl radicals with unpaired electrons and should occur rapidly owing to the sufficiently high energy content of the peroxyl-alkyl diradical (Hermans et al., 2005, 2004; Dillon et al., 2012; Olivella et al., 2001; Dibble, 2002). Note that this chemistry is very distinct from that of the singlet $\mathrm{CH}_{3} \mathrm{C}(\mathrm{OH}) \mathrm{OO}$ Criegee intermediate. The acyl radical product is expected to recombine rapidly with a second $\mathrm{O}_{2}$ molecule, forming acylperoxy radicals, $\mathrm{CH}_{3} \mathrm{C}(=\mathrm{O}) \mathrm{OO}^{\circ}$. Alternatively, the triplet $\mathrm{CH}_{3} \mathrm{C}^{\bullet}(\mathrm{OH}) \mathrm{OO}{ }^{\bullet}$ intermediate can react with a second $\mathrm{O}_{2}$ molecule by a barrierless recombination reaction (Fig. 4), forming the diperoxy singlet diradical $\mathrm{CH}_{3} \mathrm{C}(\mathrm{OH})\left(\mathrm{OO}^{\circ}\right) \mathrm{OO}^{*}$, which in turn can eliminate $\mathrm{HO}_{2}$, similar to other $\alpha-\mathrm{OH}$ peroxy radicals, forming the acylperoxy radicals directly. This second $\mathrm{O}_{2}$ addition is sufficiently exothermic to allow for formation of peracetic acid with a singlet $\mathrm{O}_{2}$ molecule, but this process has a rather large barrier of $\sim 24 \mathrm{kcal} \mathrm{mol}^{-1}$ and is expected to be a minor contributor, leaving $\mathrm{CH}_{3} \mathrm{C}(\mathrm{O}) \mathrm{O}_{2}+\mathrm{HO}_{2}$ as the likely dominant products of the overall reaction of $\mathrm{CH}_{3} \mathrm{COH}$ with oxygen molecules.

\subsubsection{Reactions of $\mathrm{CH}_{3} \mathrm{COH}$ with carboxylic acids}

Samanta et al. (2021) observed loss of $\mathrm{CH}_{3} \mathrm{COH}$ via reaction with pyruvic acid, which may indicate that its fate in the atmosphere may also be (partially) controlled by similar reactions. To theoretically investigate the reaction of $\mathrm{CH}_{3} \mathrm{COH}$ with carboxylic acids, we used formic acid in the calculations. Not only is formic acid an abundant organic acid in the atmospheric boundary layer, but also its reactivity is related to the properties of the $-\mathrm{C}(=\mathrm{O}) \mathrm{OH}$ moiety, and the results are transferable to other oxoacids, including pyruvic acid, which was present in high concentrations in most laboratory investigations.

As shown in Fig. 5, $\mathrm{CH}_{3} \mathrm{COH}$ forms strong complexes with $\mathrm{HC}(\mathrm{O}) \mathrm{OH}$, with $11 \mathrm{kcal} \mathrm{mol}^{-1}$ stability. From this complex, an addition process occurs that is best described as the transfer of the acidic $\mathrm{H}^{+}$atom to the carbene lone pair on the $\mathrm{CH}_{3} \mathrm{COH}$ central carbon, with simultaneous association of one of the negatively charged lone electron pair of the carbonyl oxygen to the carbene vacant $\mathrm{p}$ orbital, forming a 1hydroxyethyl ester $\left(\mathrm{CH}_{3} \mathrm{CH}(\mathrm{OH}) \mathrm{OC}(\mathrm{O}) \mathrm{H}\right)$. Due to the concerted association of the two carbene orbitals with suitable partners in the carboxylic moiety, this process has a very low barrier $\left(\leq 1 \mathrm{kcal} \mathrm{mol}^{-1}\right)$. This mechanism is feasible due to the size of the $-\mathrm{C}(\mathrm{O}) \mathrm{OH}$ group and the possibility of shift-

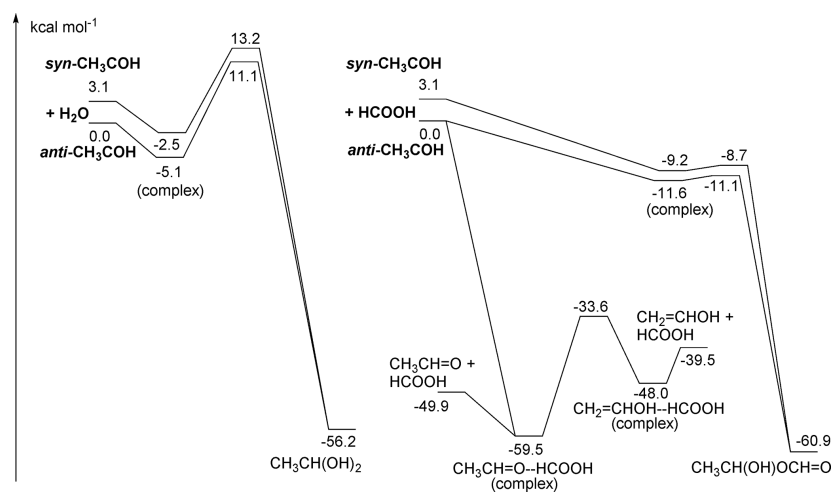

Figure 5. ZPE-corrected potential energy surface for reactions of singlet $\mathrm{CH}_{3} \mathrm{COH}$ with $\mathrm{H}_{2} \mathrm{O}$ (left) and $\mathrm{HCOOH}$ (right) at the CCSD(T)//M06-2X-D3 level of theory.

ing the double bond to the other oxygen atom upon $\mathrm{H}$-atom loss. For the anti- $\mathrm{CH}_{3} \mathrm{COH}$ carbene, we also found that an in-plane approach of the carboxylic acid towards the $\mathrm{COH}$ moiety in methylhydroxy carbene can simultaneously transfer the acidic $\mathrm{H}$ atom to the carbene carbon while the carbene hydroxy $\mathrm{H}$ atom is transferred to the carbonyl oxygen in the acid, reforming the $\mathrm{HC}(\mathrm{O}) \mathrm{OH}$ co-reactant. This catalysis reaction converts anti- $\mathrm{CH}_{3} \mathrm{COH}$ to acetaldehyde, $\mathrm{CH}_{3} \mathrm{CHO}$, without an energy barrier. Both adduct formation and the catalysis reaction should proceed with rate coefficients near the collision limit.

Carboxylic acids can also catalyse keto-enol tautomerization, possibly helping the isomerization between $\mathrm{CH}_{3} \mathrm{CHO}$ and $\mathrm{CH}_{2}=\mathrm{CH}_{2} \mathrm{OH}$ by reducing the effective barrier by over $50 \mathrm{kcal} \mathrm{mol}^{-1}$ though the thermal reaction remains slow (see Table 2). The only reaction of $\mathrm{CH}_{3} \mathrm{COH}$ that has been investigated experimentally to date is that with pyruvic acid (Samanta et al., 2021), which we also examine theoretically in the Supplement. Note that the large rate coefficient for $\mathrm{CH}_{3} \mathrm{COH}$ with organic acids calculated here would imply that reaction of thermalized $\mathrm{CH}_{3} \mathrm{COH}$ with pyruvic acid would overwhelm any other bimolecular $\mathrm{CH}_{3} \mathrm{COH}$ reaction in their work and most of the experiments listed in Table S1.

\subsubsection{Reactions of $\mathrm{CH}_{3} \mathrm{COH}$ with $\mathrm{H}_{2} \mathrm{O}$}

Based on the reactivity of small carbenes towards closedshell molecules, Samanta et al. (2021) suggested that reaction with $\mathrm{H}_{2} \mathrm{O}$ might be an important loss process of the $\mathrm{CH}_{3} \mathrm{COH}$ carbene intermediate. We have characterized the insertion reaction of $\mathrm{CH}_{3} \mathrm{COH}$ in the $\mathrm{H}_{2} \mathrm{O}$ molecule and found very high barriers, $\geq 11 \mathrm{kcal} \mathrm{mol}^{-1}$, with very low rate coefficients $\sim 10^{-20} \mathrm{~cm}^{3}$ molecule ${ }^{-1} \mathrm{~s}^{-1}$ (see Fig. 5 and Table 2). The reaction is significantly slower than with carboxylic acid as the smaller $\mathrm{H}_{2} \mathrm{O}$ molecule is unable to simultaneously reach both carbene orbitals in a favourable geometry. The reaction of $\mathrm{H}_{2} \mathrm{O}$ with $\mathrm{CH}_{3} \mathrm{COH}$ is best described as a shift of an $\mathrm{H}^{+}$atom to the carbene lone pair orbital, followed 
by migration of the water $\mathrm{HO}^{-}$moiety to the vacant carbene orbital to form a bond with a lone electron pair. The reaction is further hindered by the back-donation of the $\mathrm{CH}_{3} \mathrm{COH}$ oxygen atom into the vacant carbene orbital, partially filling the vacant carbene orbital and reducing the reactivity of the carbene functionality. We therefore propose that $\mathrm{CH}_{3} \mathrm{COH}$ will be significantly less reactive towards closed shell species than the ${ }^{2} \mathrm{CH}$ and ${ }^{1} \mathrm{CH}_{2}$ carbenes which are known to exhibit very fast insertion and cyclo-addition reactions (Vereecken et al., 1998; Goulay et al., 2009; Douglas et al., 2019; Jasper et al., 2007; Gannon et al., 2010).

\subsubsection{Summary of theoretical calculations: the fate of thermalized $\mathrm{CH}_{3} \mathrm{COH}$ in 1 bar of air}

The theoretical analysis of the fate of $\mathrm{CH}_{3} \mathrm{COH}$ carbene intermediates formed in PA photolysis indicates that the acetaldehyde formation observed in many experiments could be the result of a fast catalysis reaction of $\mathrm{CH}_{3} \mathrm{COH}$ with pyruvic acid, which under typical experimental conditions dominates over competing reactions, such as with $\mathrm{O}_{2}$, by several orders of magnitude. This conclusion is consistent with the experimental observations of Reed Harris et al. (2017a), who report a reduction in the acetaldehyde yield when low pyruvic acid concentrations are used and an increase in the formation of acetic acid (which can be formed in the reaction of $\mathrm{CH}_{3} \mathrm{C}(\mathrm{O}) \mathrm{O}_{2}$ radicals with $\left.\mathrm{HO}_{2}\right)$. In the atmospheric boundary layer atmosphere, where the concentrations of organic acids may lie between $10^{10}$ and $10^{11}$ molecule $\mathrm{cm}^{-3}$ (Millet et al., 2015) and that of $\mathrm{O}_{2}$ is close to $5 \times 10^{18}$ molecule $\mathrm{cm}^{-3}$, the reactions of $\mathrm{CH}_{3} \mathrm{COH}$ with organic acids and $\mathrm{O}_{2}$ are competitive, whereas reaction of $\mathrm{CH}_{3} \mathrm{COH}$ with water is minor. Table 2 lists the predicted rate coefficients for these reactions.

\subsection{Box-model results: contribution of pyruvic acid to acetaldehyde and radical formation}

To account for the large variability in photodissociation quantum yields and product yields reported in the literature (see above), we modelled two scenarios, A and B:

- Scenario A. In this scenario we used pyruvic acid cross sections, quantum yields, and product yields according to the IUPAC recommendations with a photodissociation quantum yield $(\varphi)$ of 0.2 at 1 bar pressure and branching ratios of $0.6,0.05$, and 0.35 for Reactions (R1), (R2), and (R3) as listed in Sect. 1.1.

- Scenario B. Here we use the same absorption crosssections as scenario A but build on the recent observations of (Samanta et al., 2021) and the theoretical work presented in Sect. 3.2, which considers the formation and fate of an excited $\mathrm{CH}_{3} \mathrm{COH}$ molecule $\left(+\mathrm{CO}_{2}\right)$. In scenario $\mathrm{B}$, we consider the effects of using photodissociation quantum yields of $0.2,0.5$, and
1 (scenarios $\mathrm{B}_{0.2}, \mathrm{~B}_{0.5}$, and $\mathrm{B}_{1}$, respectively). Photolysis at wavelengths $<340 \mathrm{~nm}$ was considered to generate $\mathrm{CH}_{3} \mathrm{CO}+\mathrm{HOCO}$, whereas photolysis at wavelengths $>340 \mathrm{~nm}$ was assumed to form $\mathrm{CO}_{2}+$ energy rich $\mathrm{CH}_{3} \mathrm{COH}^{\#}$, which undergoes the reactions outlined in Sect. 1. Assuming a quantum yield that is independent of wavelength results in $25 \%$ of pyruvic acid photolysis at noon taking place at wavelengths $<340 \mathrm{~nm}$ and $75 \%$ at wavelengths $>340 \mathrm{~nm}$. In the model, we assume that this ratio does not change (i.e. we neglect wavelength-dependent variations in the relative actinic flux through the diel cycle). The values of $25 \%$ and $75 \%$ listed above roughly correspond to the relative importance of peroxy radical formation (via Reactions R3, R4, and R5) at the shorter wavelengths compared to $\mathrm{CH}_{3} \mathrm{COH}+\mathrm{CO}_{2}$ formation (Reaction R6) at the longer wavelengths. Some experimental data indicate that addition of $\mathrm{O}_{2}$ can reduce the $\mathrm{CH}_{3} \mathrm{CHO}$ yield in favour of formation of, for example, acetic acid. For this reason we use a rate coefficient for reaction of $\mathrm{CH}_{3} \mathrm{COH}$ with $\mathrm{O}_{2}$ that is competitive with the reaction between $\mathrm{CH}_{3} \mathrm{COH}$ and organic acids. This is a factor of $\sim 10$ larger than the value obtained theoretically, but we consider this value still within the uncertainty $(\sim 1$ to $2 \mathrm{kcal} \mathrm{mol}^{-1}$ on the barrier height) of our current theoretical results as the peculiar wavefunction of $\mathrm{CH}_{3} \mathrm{COH}$ may require even higher levels of theory to be described accurately.

In the box model, in addition to reaction with $\mathrm{O}_{2}$, the thermalized carbene also reacts with formic and acetic acids to form acetaldehyde:

$\mathrm{CH}_{3} \mathrm{COH}+\mathrm{HCOOH} \rightarrow \mathrm{CH}_{3} \mathrm{CHO}+\mathrm{HCOOH}$

$\mathrm{CH}_{3} \mathrm{COH}+\mathrm{CH}_{3} \mathrm{C}(\mathrm{O}) \mathrm{OH} \rightarrow \mathrm{CH}_{3} \mathrm{CHO}+\mathrm{CH}_{3} \mathrm{C}(\mathrm{O}) \mathrm{OH}$

with a rate coefficient of $5 \times 10^{-11} \mathrm{~cm}^{3}$ molecule ${ }^{-1} \mathrm{~s}^{-1}$.

We assumed that (at 1 bar) $70 \%$ of $\mathrm{CH}_{3} \mathrm{COH}^{\#}$ was quenched to $\mathrm{CH}_{3} \mathrm{COH}, 20 \%$ isomerized to $\mathrm{CH}_{3} \mathrm{CHO}$, and $10 \%$ isomerized to $\mathrm{CH}_{2}=\mathrm{CHOH}$ in order to reproduce the $\mathrm{CH}_{3} \mathrm{CHO}$-to- $\mathrm{CH}_{2}=\mathrm{CHOH}$ ratio reported by Samanta et al. (2021). A summary reaction scheme for the photodissociation of pyruvic acid and the fate of the initial products is given in the SI.

\subsection{1 $\mathrm{CH}_{3} \mathrm{CHO}$ formation}

The modelled formation of $\mathrm{CH}_{3} \mathrm{CHO}$ from pyruvic acid photolysis through the diel cycle when considering scenario A is displayed as a stacked plot of contributing reactions in Fig. 6. Immediately apparent from this figure is the dominance of pyruvic acid photolysis compared to all other processes. Under scenario A, even with the low quantum yield $(\varphi=0.2)$ recommended by IUPAC, pyruvic acid photolysis contributes $>80 \%$ to the overall $\mathrm{CH}_{3} \mathrm{CHO}$ production term, with a maximum of $\sim 15 \%$ (at noon) arising from reactions 

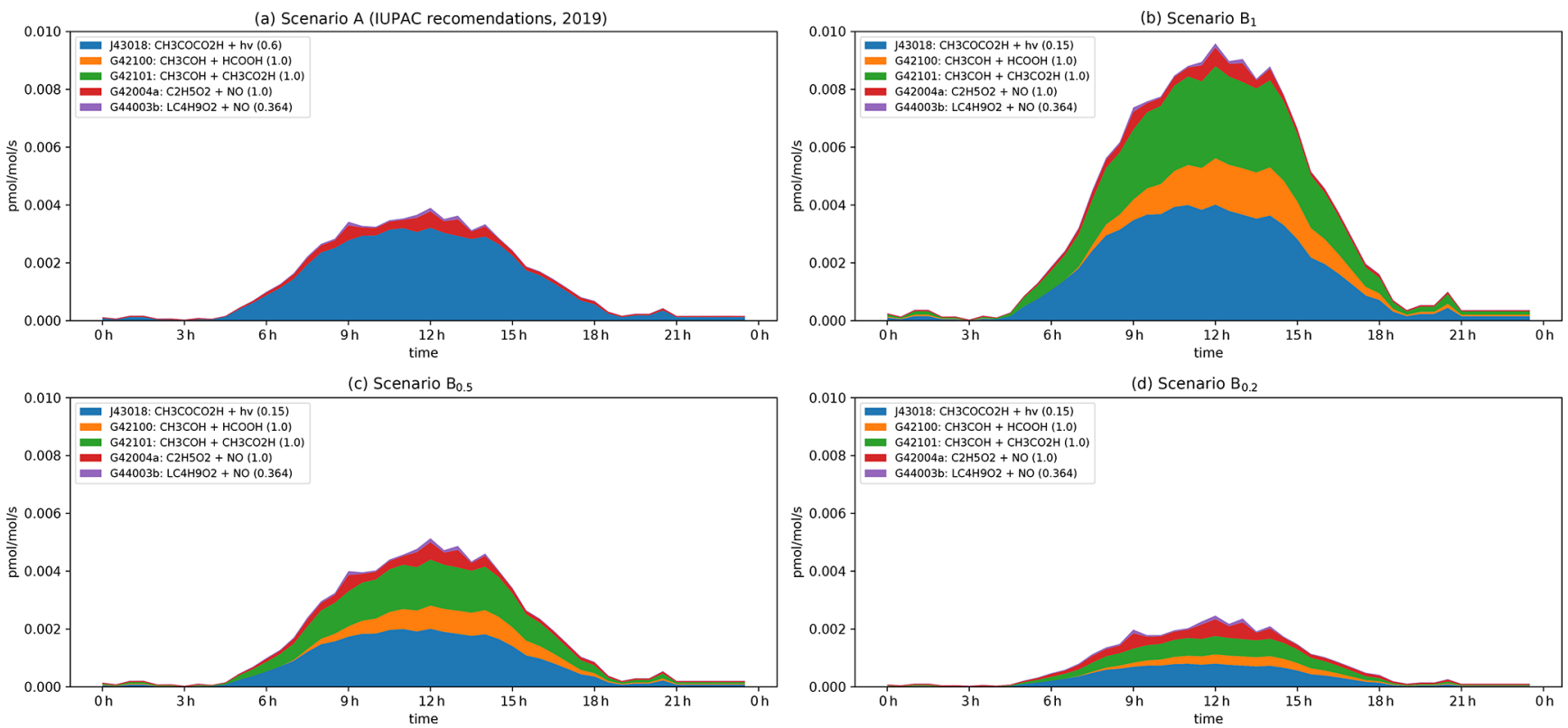

Figure 6. Modelled rates of $\mathrm{CH}_{3} \mathrm{CHO}$ formation (in pptv s${ }^{-1}$ ) through the diel cycle from photolysis of pyruvic acid (blue, orange, and green) and other reactions during IBAIRN. (a) Scenario A (IUPAC). (b) Scenario $\mathrm{B}_{1}$. (c) Scenario $\mathrm{B}_{0.5}$. (d) Scenario $\mathrm{B}_{0.2}$. In the legend, the first term is the equation tag used by CAABA/MECCA for the reaction. $\mathrm{LC} 4 \mathrm{H} 9 \mathrm{O} 2$ is the peroxy radical formed in the reaction of $\mathrm{OH}$ with butane. A full listing of the reactions can be downloaded (see Data availability section).

of the ethylperoxy radical, formed in the reaction of $\mathrm{OH}$ with ethane $(7.5 \%)$ and butane $(3.75 \%)$ and in the photolysis of $\mathrm{CH}_{3} \mathrm{C}(\mathrm{O}) \mathrm{C}_{2} \mathrm{H}_{5}(3.75 \%)$.

Under scenario $\mathrm{B}$, pyruvic acid photolysis still dominates the formation of $\mathrm{CH}_{3} \mathrm{CHO}$, with a noontime contribution of $91 \%, 86 \%$, and $71 \%$ when quantum yields of $1,0.5$, and 0.2 are considered. Of the pyruvic acid contribution, $45 \%$ of the $\mathrm{CH}_{3} \mathrm{CHO}$ arises via isomerization of the initially formed, energized carbene (blue), while the remaining $55 \%$ results from reactions of the thermalized carbene with formic (orange) and acetic (green) acids, the concentrations of which were constrained by observations. The modelled, noontime mixing ratio of $\mathrm{CH}_{3} \mathrm{CHO}$ varies from $400 \mathrm{pptv}$ (scenario $\mathrm{B}_{1}$ ) to 160 pptv (scenario $\mathrm{B}_{0.2}$ ) when pyruvic acid photolysis is included and is reduced to $\sim 100 \mathrm{pptv}$ when the quantum yield is set to zero. Unfortunately, reliable measurements of the $\mathrm{CH}_{3} \mathrm{CHO}$ mixing ratios with which to compare the model simulations were not available for the IBAIRN campaign as the in situ PTR-MS data set $(m / z 45)$ varied from -400 to $+400 \mathrm{pptv}$ over the diel cycle. The modelled, maximum mixing ratio of $\mathrm{CH}_{3} \mathrm{CHO}$ increases from $\sim 100 \mathrm{pptv}$ when pyruvic acid photolysis is neglected to $>400$ pptv under scenario $\mathrm{B}_{1}$ (see Fig. S6).

\subsection{2 $\mathrm{CH}_{3} \mathrm{C}(\mathrm{O}) \mathrm{O}_{2}$ formation}

The $\mathrm{CH}_{3} \mathrm{C}(\mathrm{O}) \mathrm{O}_{2}$ radical is formed in a termolecular reaction between the $\mathrm{CH}_{3} \mathrm{CO}$ radical and $\mathrm{O}_{2}$. Figure 7 displays the main photochemical reactions that lead to the formation of
$\mathrm{CH}_{3} \mathrm{CO}$ in our model. The spikes in the simulated production rates are connected to spikes in the diel average NO mixing ratio at the site. In analysing the data, we therefore consider not only the contributions at noon (when NO mixing ratios were large), but also at 10:30 when NO mixing ratios were comparably low.

Under scenario A, where $\varphi=0.2$ and the yield of the $\mathrm{CH}_{3} \mathrm{CO}$ radical is 0.35 , the contribution of pyruvic acid photolysis to the overall production rate at 12:00 and 10:30 is about $23 \%$ and $16 \%$, respectively, roughly equally divided into a direct contribution (J43018) and an indirect contribution (G42008a) arising via enhanced $\mathrm{CH}_{3} \mathrm{CHO}$ levels. The main contributors to the formation of $\mathrm{CH}_{3} \mathrm{CO}$ are reactions initiated by the degradation of isoprene and MTs (in the legend of Fig. 7: BIACETO2, C511O2, C716O2, $\mathrm{CO} 23 \mathrm{C} 4 \mathrm{CHO}, \mathrm{CO} 235 \mathrm{C} 6 \mathrm{CHO}$ ), which involve reactions of peroxy radicals with $\mathrm{NO}$.

Under scenario $\mathrm{B}_{1}$, the photolysis of pyruvic acid becomes significantly more important, contributing a total of $63 \%$ of the total production rate for $\mathrm{CH}_{3} \mathrm{CO}$ at $10: 30$ and $42 \%$ at 12:00. When considering scenarios $\mathrm{B}_{0.5}$ and $\mathrm{B}_{0.2}$ the contributions of pyruvic acid photolysis are reduced to $46 \%$ (29\%) and $29 \%(17 \%)$, respectively, where the numbers in parentheses are for the "high- $\mathrm{NO}_{x}$ " situation. Generally, the reaction of the thermalized carbene with $\mathrm{O}_{2}$ (G42099), the direct photolysis at wavelengths $<340 \mathrm{~nm}$ (J43018), and the indirect enhancement in $\mathrm{CH}_{3} \mathrm{CO}$ formation via the enhanced levels of $\mathrm{CH}_{3} \mathrm{CHO}$ (G42008a) contribute roughly equally to the formation of $\mathrm{CH}_{3} \mathrm{CO}$ resulting from pyruvic acid photol- 

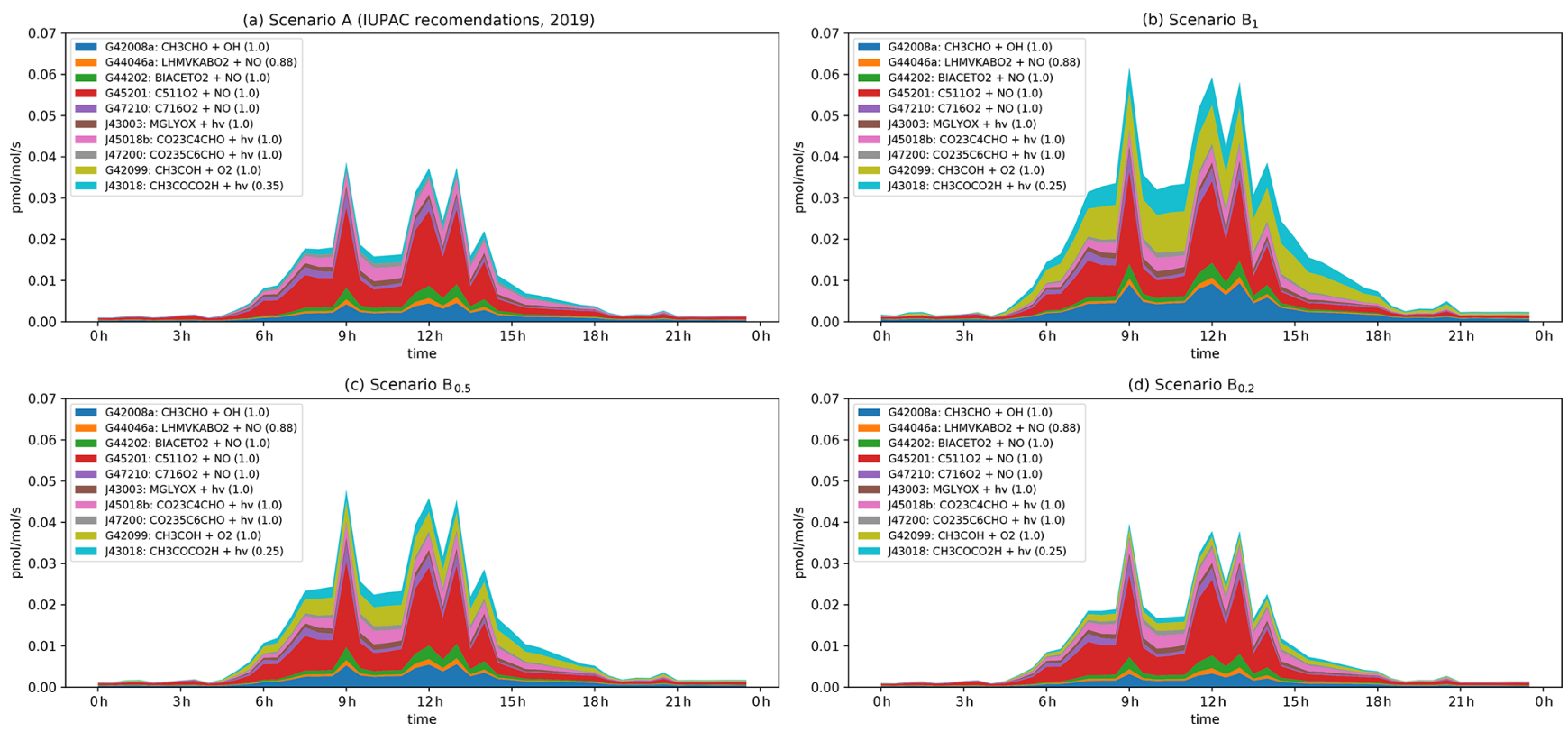

Figure 7. Modelled rates of $\mathrm{CH}_{3} \mathrm{CO}$ formation (in pptv s${ }^{-1}$ ) through the diel cycle from photolysis of pyruvic acid (blue, orange, and green) and other photochemical processes during IBAIRN. (a) Scenario A (IUPAC). (b) Scenario $B_{1}$. (c) Scenario $B_{0.5}$ (c) Scenario $B_{0.2}$. In the legend, the first term is the equation tag used by CAABA/MECCA for the reaction. A full listing of the reactions can be downloaded (see Data availability section).
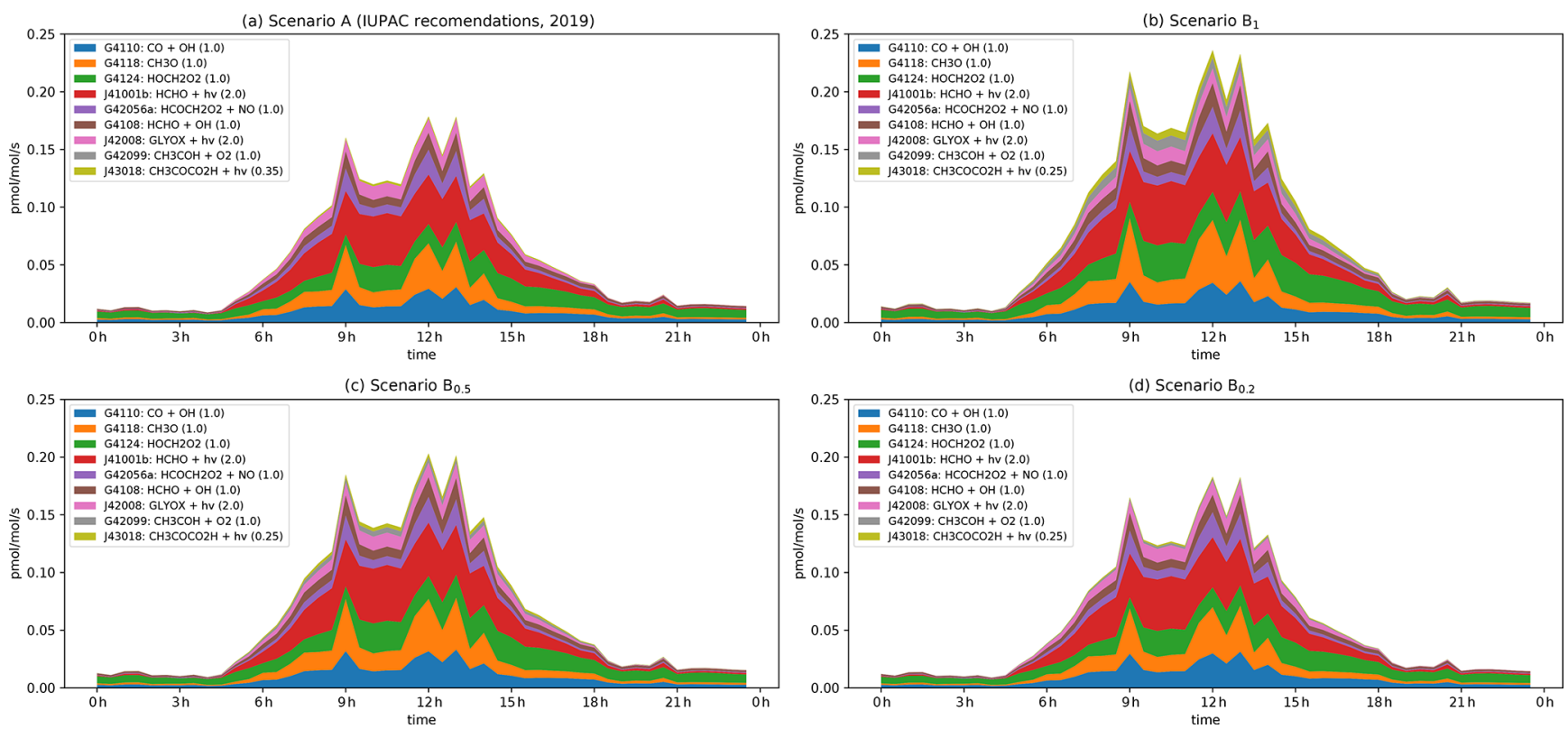

Figure 8. Modelled rates of $\mathrm{HO}_{2}$ formation (in pptv s ${ }^{-1}$ ) through the diel cycle from photolysis of pyruvic acid (blue, orange, and green) and

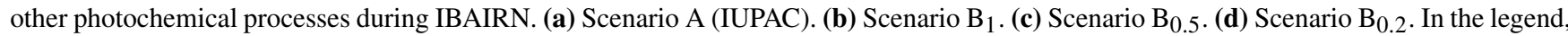
the first term is the MCM designation for the reaction. A full listing of the reactions can be downloaded (see Data availability section). 
ysis. The modelled mixing ratio of the $\mathrm{CH}_{3} \mathrm{C}(\mathrm{O}) \mathrm{O}_{2}$ radical at noon increases by a factor of $\sim 1.5$ when comparing scenario $\mathrm{B}_{1}$ with the quantum yields for pyruvic acid photodissociation set to zero.

\subsection{3 $\mathrm{HO}_{2}$ formation}

In Fig. 8, we plot the nine most important model pathways to $\mathrm{HO}_{2}$ production through the diel cycle. The dominant modelled production terms for $\mathrm{HO}_{2}$ involve $\mathrm{HCHO}$ (photolysis $\mathrm{HCHO}$ and reaction with $\mathrm{OH}, \mathrm{G} 4108, \mathrm{~J} 41001 \mathrm{~b}$ ), the reaction of methoxy radicals $\left(\mathrm{G} 4118\right.$, whereby $\mathrm{CH}_{3} \mathrm{O}$ is generated mainly in the reaction of $\mathrm{CH}_{3} \mathrm{O}_{2}$ radicals with $\mathrm{NO}$ ), and the reaction of $\mathrm{OH}$ with $\mathrm{CO}$. The direct contribution of pyruvic acid photolysis to $\mathrm{HO}_{2}$ formation (via its photolysis (J43018) and through the reaction of $\mathrm{CH}_{3} \mathrm{COH}$ with $\mathrm{O}_{2}, \mathrm{G} 42099$ ) is $\sim 10 \%$ under scenario $\mathrm{B}_{1}$ under low- $\mathrm{NO}_{x}$ conditions (i.e. at 10:30). Under all other scenarios it is lower, with values (in percent) of $<1$ (scenario $A$ at both 10:30 and 02:00), $\sim 6$ (scenario $\mathrm{B}_{1}$ at 12:00), $\sim 5$ and $\sim 3.5$ (scenario $\mathrm{B}_{0.5}$ at 10:30 and 12:00, respectively), and $\sim 1.5$ and $<1$ (scenario $\mathrm{B}_{0.2}$ at 10:30 and 12:00, respectively). However, although the direct impact of pyruvic acid photolysis is weak, it has a significant indirect effect via the enhanced formation of $\mathrm{CH}_{3} \mathrm{C}(\mathrm{O}) \mathrm{O}_{2}$ radicals (directly via Reactions $\mathrm{R} 3+\mathrm{R} 4$ and $\mathrm{R} 10$ and indirectly via $\mathrm{CH}_{3} \mathrm{CHO}$ formation), which, in the presence of $\mathrm{O}_{2}$, reacts with $\mathrm{NO}$ to form $\mathrm{CH}_{3} \mathrm{O}_{2}$. Enhanced production rates of $\mathrm{CH}_{3} \mathrm{O}_{2}$ result in enhanced production rates of $\mathrm{CH}_{3} \mathrm{O}$ and $\mathrm{HCHO}$ and thus $\mathrm{HO}_{2}$.

$$
\begin{aligned}
& \mathrm{CH}_{3} \mathrm{C}(\mathrm{O}) \mathrm{O}_{2}+\mathrm{NO}\left(+\mathrm{O}_{2}\right) \rightarrow \mathrm{CH}_{3} \mathrm{O}_{2}+\mathrm{NO}_{2}+\mathrm{CO}_{2} \\
& \mathrm{CH}_{3} \mathrm{O}_{2}+\mathrm{NO} \rightarrow \mathrm{CH}_{3} \mathrm{O}+\mathrm{NO}_{2} \\
& \mathrm{CH}_{3} \mathrm{O}+\mathrm{O}_{2} \rightarrow \mathrm{HCHO}+\mathrm{HO}_{2} \\
& \mathrm{HCHO}+h v\left(+2 \mathrm{O}_{2}\right) \rightarrow 2 \mathrm{HO}_{2}+\mathrm{CO}
\end{aligned}
$$

The model simulations have shown that the photolysis of pyruvic acid at the levels observed during the IBAIRN campaign has a potentially significant effect on both $\mathrm{CH}_{3} \mathrm{CHO}$ mixing ratios and production rates of $\mathrm{HO}_{2}$ and $\mathrm{CH}_{3} \mathrm{C}(\mathrm{O}) \mathrm{O}_{2}$ radicals, the latter being especially enhanced under low- $\mathrm{NO}_{x}$ conditions. The enhanced production rates and concentrations of $\mathrm{CH}_{3} \mathrm{C}(\mathrm{O}) \mathrm{O}_{2}$ and $\mathrm{HO}_{2}$ also result in significant increases in the modelled mixing ratios of several trace gases that are formed from these radicals. Comparing scenario $\mathrm{B}_{1}$ to the case in which the pyruvic acid photodissociation quantum yield $(\varphi)$ is set to zero results in an increase by factors of 2.2, 2.0, and 1.6 for $\mathrm{CH}_{3} \mathrm{C}(\mathrm{O}) \mathrm{OOH}, \mathrm{CH}_{3} \mathrm{OOH}$, and $\mathrm{H}_{2} \mathrm{O}_{2}$, respectively (see Fig. S6). $\mathrm{HCHO}$ mixing ratios are enhanced by a factor of 1.2. Vinyl alcohol mixing ratios of up to $40 \mathrm{pptv}$ were generated in scenario $\mathrm{B}_{1}$. Clearly, the photolysis of pyruvic acid can potentially impact strongly on the concentrations of, for example, $\mathrm{C} 1$ and $\mathrm{C} 2$ carbonyl compounds and peroxides in the boreal environment.

\section{Conclusions}

We have combined measurements of pyruvic acid in an autumn campaign in the boreal forest (IBAIRN) with theoretical calculations designed to characterize the fate of the methylhydroxy carbene radical $\left(\mathrm{CH}_{3} \mathrm{COH}\right.$, the major product of pyruvic acid photodissociation) with a box-modelling study. We investigated the impact of pyruvic acid photolysis on the rates of production of acetaldehyde $\left(\mathrm{CH}_{3} \mathrm{CHO}\right)$ and the peroxy radicals $\mathrm{CH}_{3} \mathrm{C}(\mathrm{O}) \mathrm{O}_{2}$ and $\mathrm{HO}_{2}$. The theoretical study revealed unexpected features of $\mathrm{CH}_{3} \mathrm{COH}$ chemistry, including slow reactions of thermalized carbene with $\mathrm{H}_{2} \mathrm{O}$ but an efficient acid-catalysed conversion to $\mathrm{CH}_{3} \mathrm{CHO}$ in the presence of organic acids such as $\mathrm{HC}(\mathrm{O}) \mathrm{OH}$. The reaction of $\mathrm{CH}_{3} \mathrm{COH}$ with $\mathrm{O}_{2}$ is slow but will contribute to its fate (and thus the formation of $\mathrm{CH}_{3} \mathrm{C}(\mathrm{O}) \mathrm{O}_{2}$ and $\left.\mathrm{HO}_{2}\right)$ in the lower atmosphere where $\mathrm{O}_{2}$ concentrations are high if the rate constant used (elevated by an order of magnitude compared to the theoretical value) is correct.

In our box model, the photolysis of pyruvic acid was parameterized as presently recommended by IUPAC (whereby the main products are $\mathrm{CH}_{3} \mathrm{CHO}$ and $\mathrm{CO}_{2}$ ) and also using a more detailed mechanism in which the formation and fate of $\mathrm{CH}_{3} \mathrm{COH}$ was considered and in which the quantum yield was varied. In all scenarios, we find that the photolysis of pyruvic acid was the dominant source of $\mathrm{CH}_{3} \mathrm{CHO}$ during IBAIRN and that its instantaneous contribution to the daytime formation of $\mathrm{CH}_{3} \mathrm{C}(\mathrm{O}) \mathrm{O}_{2}$ varied between $16 \%$ and $63 \%$, dependent on the assumed scenario and also on the NO concentration. Pyruvic acid photodissociation results in a significant increase in the mixing ratios of several carbonyl compounds and peroxides in the boreal environment.

The results of our modelling study are strongly dependent on the chosen quantum yields and photodissociation mechanism. To reduce the uncertainty in the role of pyruvic acid photolysis, there is an urgent need for further experimental and theoretical work on the photochemistry of pyruvic acid and on the fate of methylhydroxy carbene under atmospheric conditions. In addition, further measurements of pyruvic acid mixing ratios and of its deposition velocity in different environments are required to better constrain its abundance and lifetime and thus the impact of its photolysis. Enclosure studies would be helpful to investigate the dependence of pyruvic acid emission rates on different plant types and environmental conditions.

Data availability. The Max Planck Institute data used for the IBAIRN analysis and the reaction scheme used in the box model are archived at https://doi.org/10.5281/zenodo.3254828 (Crowley and Fischer, 2019).

Supplement. The supplement related to this article is available online at: https://doi.org/10.5194/acp-21-14333-2021-supplement. 
Author contributions. PGE was responsible for the pyruvic acid measurement during IBAIRN. PGE and JNC, with contributions from JL, wrote the manuscript. LV conducted the theoretical calculation on the fate of methylhydroxy carbene, RS and AP did the box modelling, and NS was responsible for the CRDS measurements of $\mathrm{NO}_{2}$ and PANs during IBAIRN. JS was responsible for the $\mathrm{O}_{3}$ and $J$ value measurements during IBAIRN. HF was responsible for the NO and CO measurements during IBAIRN. EK and JW were responsible for the MT measurements during IBAIRN. VV was responsible for the mixing layer height measurements during IBAIRN. TP was responsible for the SMEAR II observations and infrastructure. All authors contributed to the paper.

Competing interests. The authors declare that they have no conflict of interest.

Disclaimer. Publisher's note: Copernicus Publications remains neutral with regard to jurisdictional claims in published maps and institutional affiliations.

Acknowledgements. We thank the technical staff of SMEAR II station for the excellent support during IBAIRN.

Financial support. This research has been supported by the ENVRIplus (grant no. 654182). We are grateful to ENVRIplus for partial financial support of the IBAIRN campaign.

The article processing charges for this open-access publication were covered by the Max Planck Society.

Review statement. This paper was edited by Gabriele Stiller and reviewed by two anonymous referees.

\section{References}

Aalto, J., Porcar-Castell, A., Atherton, J., Kolari, P., Pohja, T., Hari, P., Nikinmaa, E., Petaja, T., and Back, J.: Onset of photosynthesis in spring speeds up monoterpene synthesis and leads to emission bursts, Plant Cell Environ., 38, 2299-2312, https://doi.org/10.1111/pce.12550, 2015.

Alecu, I. M., Zheng, J. J., Zhao, Y., and Truhlar, D. G.: Computational thermochemistry: scale factor databases and scale factors for vibrational frequencies obtained from electronic model chemistries, J. Chem. Theor. Comput., 6, 2872-2887, https://doi.org/10.1021/ct100326h, 2010.

Andreae, M. O., Talbot, R. W., and Li, S. M.: Atmospheric measurements of pyruvic and formic acid, J. Geophys. Res.-Atmos., 92, 6635-6641, https://doi.org/10.1029/JD092iD06p06635, 1987.

Berges, M. G. M. and Warneck, P.: Product quantum yields for the $350 \mathrm{~nm}$ photodecomposition of pyruvicacid in air, Ber. Bunsen Phys. Chem., 96, 413-416, https://doi.org/10.1002/bbpc.19920960334, 1992.
Burkholder, J. B., Sander, S. P., Abbatt, J., Barker, J. R., Huie, R. E., Kolb, C. E., Kurylo, M. J., Orkin, V. L., Wilmouth, D. M., and Wine, P. H.: Chemical Kinetics and Photochemical Data for Use in Atmospheric Studies, Evaluation No. 18, JPL Publication 15-10, Jet Propulsion Laboratory, Pasadena, available at: http: //jpldataeval.jpl.nasa.gov (last access: September 2020), 2015.

Calvert, J. G., Mellouki, A., Pilling, M. J., and Wallington, T. J.: The Mechanisms of Atmospheric Oxidation of the Oxygenates, Oxford Univ. Press, New York, 2011.

Chang, X.-P., Fang, Q., and Cui, G.: Mechanistic photodecarboxylation of pyruvic acid: Excited-state proton transfer and three-state intersection, J. Chem. Phys., 141, 154311, https://doi.org/10.1063/1.4898085, 2014.

Crowley, J. N. and Fischer, H.: IBAIRN data (Boreal forest, Hyytiälä Sept. 2016) Max-Planck-Institut, Mainz [data set], Zenodo, https://doi.org/10.5281/zenodo.3254828, 2019.

Crowley, J. N., Pouvesle, N., Phillips, G. J., Axinte, R., Fischer, H., Petäjä, T., Nölscher, A., Williams, J., Hens, K., Harder, H., Martinez-Harder, M., Novelli, A., Kubistin, D., Bohn, B., and Lelieveld, J.: Insights into $\mathrm{HO}_{x}$ and $\mathrm{RO}_{x}$ chemistry in the boreal forest via measurement of peroxyacetic acid, peroxyacetic nitric anhydride (PAN) and hydrogen peroxide, Atmos. Chem. Phys., 18, 13457-13479, https://doi.org/10.5194/acp-18-134572018, 2018.

Dee, D. P., Uppala, S. M., Simmons, A. J., Berrisford, P., Poli, P., Kobayashi, S., Andrae, U., Balmaseda, M. A., Balsamo, G., Bauer, P., Bechtold, P., Beljaars, A. C. M., van de Berg, L., Bidlot, J., Bormann, N., Delsol, C., Dragani, R., Fuentes, M., Geer, A. J., Haimberger, L., Healy, S. B., Hersbach, H., Hólm, E. V., Isaksen, L., Kållberg, P., Köhler, M., Matricardi, M., McNally, A. P., Monge-Sanz, B. M., Morcrette, J.-J., Park, B.-K., Peubey, C., de Rosnay, P., Tavolato, C., Thépaut, J.-N., and Vitart, F.: The ERA-Interim reanalysis: configuration and performance of the data assimilation system, Q. J. Roy. Meteorol. Soc., 137, 553597, https://doi.org/10.1002/qj.828, 2011.

Dibble, T. S.: Mechanism and dynamics of the $\mathrm{CH}_{2} \mathrm{OH}+\mathrm{O}_{2}$ reaction, Chem. Phys. Lett., 355, 193-200, https://doi.org/10.1016/S0009-2614(02)00211-7, 2002.

Dillon, T. J., Pozzer, A., Vereecken, L., Crowley, J. N., and Lelieveld, J.: Does acetone react with $\mathrm{HO}_{2}$ in the upper-troposphere?, Atmos. Chem. Phys., 12, 1339-1351, https://doi.org/10.5194/acp-12-1339-2012, 2012.

Douglas, K. M., Blitz, M. A., Feng, W. H., Heard, D. E., Plane, J. M. C., Rashid, H., and Seakins, P. W.: Low temperature studies of the rate coefficients and branching ratios of reactive loss vs quenching for the reactions of $\left(\mathrm{CH}_{2}\right)-\mathrm{C}-1$ with $\mathrm{C}_{2} \mathrm{H}_{6}, \mathrm{C}_{2} \mathrm{H}_{4}, \mathrm{C}_{2} \mathrm{H}_{2}$, Icarus, 321, 752-766, https://doi.org/10.1016/j.icarus.2018.12.027, 2019.

Dunning, T. H.: Gaussian-basis sets for use in correlated molecular calculations. 1. the atoms boron through neon and hydrogen, J. Chem. Phys., 90, 1007-1023, https://doi.org/10.1063/1.456153, 1989.

Eckart, C.: The penetration of a potential barrier by electrons, Phys. Rev., 35, 1303-1309, https://doi.org/10.1103/PhysRev.35.1303, 1930.

Eger, P. G., Schuladen, J., Sobanski, N., Fischer, H., Karu, E., Williams, J., Riva, M., Zha, Q., Ehn, M., Quéléver, L. L. J., Schallhart, S., Lelieveld, J., and Crowley, J. N.: Pyruvic acid in the boreal forest: gas-phase mixing ratios and impact 
on radical chemistry, Atmos. Chem. Phys., 20, 3697-3711, https://doi.org/10.5194/acp-20-3697-2020, 2020.

Eugene, A. J., Pillar, E. A., Colussi, A. J., and Guzman, M. I.: Enhanced Acidity of Acetic and Pyruvic Acids on the Surface of Water, Langmuir, 34, 9307-9313, https://doi.org/10.1021/acs.langmuir.8b01606, 2018.

Fischer, H., Axinte, R., Bozem, H., Crowley, J. N., Ernest, C., Gilge, S., Hafermann, S., Harder, H., Hens, K., Janssen, R. H. H., Königstedt, R., Kubistin, D., Mallik, C., Martinez, M., Novelli, A., Parchatka, U., Plass-Dülmer, C., Pozzer, A., Regelin, E., Reiffs, A., Schmidt, T., Schuladen, J., and Lelieveld, J.: Diurnal variability, photochemical production and loss processes of hydrogen peroxide in the boundary layer over Europe, Atmos. Chem. Phys., 19, 11953-11968, https://doi.org/10.5194/acp-1911953-2019, 2019.

Fischer, L., Breitenlechner, M., Canaval, E., Scholz, W., Striednig, M., Graus, M., Karl, T. G., Petäjä, T., Kulmala, M., and Hansel, A.: First Eddy Covariance Flux Measurements of Semi Volatile Organic Compounds with the PTR3-TOF-MS, Atmos. Meas. Tech. Discuss. [preprint], https://doi.org/10.5194/amt-2021-117, in review, 2021.

Frisch, M. J., Trucks, G. W., Schlegel, H. B., Scuseria, G. E., Robb, M. A., Cheeseman, J. R., Scalmani, G., Barone, V., Mennucci, B., Petersson, G. A., Nakatsuji, H., Li, X., Caricato, M., Marenich, A. V., Bloino, J., Janesko, B. G., Gomperts, R., Mennucci, B., Hratchian, H. P., Ortiz, J. V., Izmaylov, A. F., Sonnenberg, J. L., Williams-Young, D., Ding, F., Lipparini, F., Egidi, F., Goings, J., Peng, B., Petrone, A., Henderson, T., Ranasinghe, D., Zakrzewski, V. G., Gao, J., Rega, N., Zheng, G., Liang, W., Hada, M., Eara, M., Toyota, K., Fukuda, R., Hasegawa, J., Ishida, M., Nakajima, T., Honda, Y., Kitao, O., Nakai, H., Vreven, T., Throssell, K., Mntgomery, Jr., J. A., Peralta, J. E., Ogliaro, F., Bearpark, M. J., Heyd, J. J., Brothers, E. N., Kudin, K. N., Staroverov, V. N., Keith, T. A., Kobayashi, R., Normand, J., Raghavachari, K., Rendell, A. P., Burant, J. C., Iyengar, S. S., Tomasi, J., Cossi, M., Millam, J. M., Klene, M., Adamo, C., Cammi, R., Ochterski, J. W., Martin, R. L., Morokuma, K., Farkas, O., Foresman, J. B., and Fox, D. J.: Gaussian 16, Revision B.01, Gaussian Inc., Wallington, CT, 2016.

Gannon, K. L., Blitz, M. A., Liang, C. H., Pilling, M. J., Seakins, P. W., and Glowacki, D. R.: Temperature Dependent Kinetics (195-798 K) and H Atom Yields (298-498 K) from Reactions of $\left(\mathrm{CH}_{2}\right)-\mathrm{C}-1$ with Acetylene, Ethene, and Propene, J. Phys. Chem. A, 114, 9413-9424, https://doi.org/10.1021/jp102276j, 2010.

Gaona-Colman, E., Blanco, M. B., Barnes, I., Wiesen, P., and Teruel, M. A.: OH- and O-3-initiated atmospheric degradation of camphene: temperature dependent rate coefficients, product yields and mechanisms, RSC Adv., 7, 2733-2744, https://doi.org/10.1039/c6ra26656h, 2017.

Goulay, F., Trevitt, A. J., Meloni, G., Selby, T. M., Osborn, D. L., Taatjes, C. A., Vereecken, L., and Leone, S. R.: Cyclic Versus Linear Isomers Produced by Reaction of the Methylidyne Radical $(\mathrm{CH})$ with Small Unsaturated Hydrocarbons, J. Am. Chem. Soc., 131, 993-1005, https://doi.org/10.1021/ja804200v, 2009.

Grimme, S., Ehrlich, S., and Goerigk, L.: Effect of the Damping Function in Dispersion Corrected Density Functional Theory, J. Comput. Chem., 32, 1456-1465, https://doi.org/10.1002/jcc.21759, 2011.
Grosjean, D.: Atmospheric reactions of pyruvic acid, Atmos. Environ., 17, 2379-2382, https://doi.org/10.1016/00046981(83)90242-1, 1983.

Grosjean, D.: Atmospheric reactions of ortho cresol: gas phase and aerosol products, Atmos. Environ., 18, 1641-1652, https://doi.org/10.1016/0004-6981(84)90386-X, 1984.

Grosjean, D., Williams, E. L., and Grosjean, E.: Atmospheric chemistry of isoprene and of its carbonyl products, Environ. Sci. Technol., 27, 830-840, https://doi.org/10.1021/es00042a004, 1993.

Guenther, A. B., Zimmerman, P. R., Harley, P. C., Monson, R. K., and Fall, R.: Isoprene and monoterpene emission rate variability - model evaluations and sensitivity analyses, J. Geophys. Res.Atmos., 98, 12609-12617, https://doi.org/10.1029/93jd00527, 1993.

Hakola, H., Hellén, H., and Laurila, T.: Ten years of light hydrocarbons $\left(\mathrm{C}_{2}-\mathrm{C}_{6}\right)$ concentration measurements in background air in Finland, Atmos. Environ., 40, 3621-3630, https://doi.org/10.1016/j.atmosenv.2005.08.019, 2006.

Hallquist, M., Wenger, J. C., Baltensperger, U., Rudich, Y., Simpson, D., Claeys, M., Dommen, J., Donahue, N. M., George, C., Goldstein, A. H., Hamilton, J. F., Herrmann, H., Hoffmann, T., Iinuma, Y., Jang, M., Jenkin, M. E., Jimenez, J. L., Kiendler-Scharr, A., Maenhaut, W., McFiggans, G., Mentel, Th. F., Monod, A., Prévôt, A. S. H., Seinfeld, J. H., Surratt, J. D., Szmigielski, R., and Wildt, J.: The formation, properties and impact of secondary organic aerosol: current and emerging issues, Atmos. Chem. Phys., 9, 5155-5236, https://doi.org/10.5194/acp9-5155-2009, 2009.

Hari, P. and Kulmala, M.: Station for Measuring EcosystemAtmosphere Relations (SMEAR II), Boreal Environ. Res., 10, 315-322, https://doi.org/10.1007/978-94-007-5603-8_9, 2005.

Helas, G., Bingemer, H., and Andreae, M. O.: Organic acids over equatorial Africa: Results from DECAFE 88, J. Geophys. Res.Atmos., 97, 6187-6193, https://doi.org/10.1029/91jd01438, 1992.

Hellén, H., Kouznetsov, R., Anttila, P., and Hakola, H.: Increasing influence of easterly air masses on NMHC concentrations at the Pallas-Sodankylä GAW station, Boreal Environ. Res., 20, 542552, 2015.

Hellén, H., Praplan, A. P., Tykkä, T., Ylivinkka, I., Vakkari, V., Bäck, J., Petäjä, T., Kulmala, M., and Hakola, H.: Longterm measurements of volatile organic compounds highlight the importance of sesquiterpenes for the atmospheric chemistry of a boreal forest, Atmos. Chem. Phys., 18, 13839-13863, https://doi.org/10.5194/acp-18-13839-2018, 2018.

Hermans, I., Nguyen, T. L., Jacobs, P. A., and Peeters, J.: Tropopause chemistry revisited: $\mathrm{HO}_{2}$-initiated oxidation as an efficient acetone sink, J. Am. Chem. Soc., 126, 9908-9909, https://doi.org/10.1021/ja0467317, 2004.

Hermans, I., Muller, J. F., Nguyen, T. L., Jacobs, P. A., and Peeters, J.: Kinetics of alpha-hydroxy-alkylperoxyl radicals in oxidation processes. $\mathrm{HO}_{2}$ center dot-initiated oxidation of ketones/aldehydes near the tropopause, J. Phys. Chem. A, 109, 4303-4311, 2005.

IUPAC Task Group on Atmospheric Chemical Kinetic Data Evaluation (Ammann, M., Cox, R. A., Crowley, J. N., Herrmann, H., Jenkin, M. E., McNeill, V. F., Mellouki, A., Rossi, M. J., Troe, J., and Wallington, T. J.): Evaluated kinetic and photochemical data 
for atmospheric chemistry, available at: http://iupac.pole-ether. fr/index.html, last access: June 2021.

Jacob, D. J. and Wofsy, S. C.: Photochemistry of biogenic emissions over the Amazon forest, J. Geophys. Res.-Atmos., 93, 14771486, https://doi.org/10.1029/JD093iD02p01477, 1988.

Jardine, K., Abrell, L., Kurc, S. A., Huxman, T., Ortega, J., and Guenther, A.: Volatile organic compound emissions from Larrea tridentata (creosotebush), Atmos. Chem. Phys., 10, 1219112206, https://doi.org/10.5194/acp-10-12191-2010, 2010a.

Jardine, K. J., Sommer, E. D., Saleska, S. R., Huxman, T. E., Harley, P. C., and Abrell, L.: Gas Phase Measurements of Pyruvic Acid and Its Volatile Metabolites, Environ. Sci. Technol., 44, 24542460, https://doi.org/10.1021/es903544p, 2010b.

Jasper, A. W., Klippenstein, S. J., and Harding, L. B.: Secondary Kinetics of Methanol Decomposition: Theoretical Rate Coefficients for $3 \mathrm{CH}^{2}+\mathrm{OH}, 3 \mathrm{CH}_{2}+3 \mathrm{CH}_{2}$, and $3 \mathrm{CH}_{2}+\mathrm{CH}_{3}$, J. Phys. Chem. A, 111, 8699-8707, https://doi.org/10.1021/jp0736950, 2007.

Johnston, H. S. and Heicklen, J.: Tunnelling corrections for unsymmetrical eckart potential energy barriers, J. Phys. Chem., 66, 532-533, https://doi.org/10.1021/j100809a040, 1962.

Kanakidou, M., Seinfeld, J. H., Pandis, S. N., Barnes, I., Dentener, F. J., Facchini, M. C., Van Dingenen, R., Ervens, B., Nenes, A., Nielsen, C. J., Swietlicki, E., Putaud, J. P., Balkanski, Y., Fuzzi, S., Horth, J., Moortgat, G. K., Winterhalter, R., Myhre, C. E. L., Tsigaridis, K., Vignati, E., Stephanou, E. G., and Wilson, J.: Organic aerosol and global climate modelling: a review, Atmos. Chem. Phys., 5, 1053-1123, https://doi.org/10.5194/acp-5-10532005, 2005.

Liebmann, J., Karu, E., Sobanski, N., Schuladen, J., Ehn, M., Schallhart, S., Quéléver, L., Hellen, H., Hakola, H., Hoffmann, T., Williams, J., Fischer, H., Lelieveld, J., and Crowley, J. N.: Direct measurement of $\mathrm{NO}_{3}$ radical reactivity in a boreal forest, Atmos. Chem. Phys., 18, 3799-3815, https://doi.org/10.5194/acp18-3799-2018, 2018a.

Liebmann, J. M., Muller, J. B. A., Kubistin, D., Claude, A., Holla, R., Plass-Dülmer, C., Lelieveld, J., and Crowley, J. N.: Direct measurements of $\mathrm{NO}_{3}$ reactivity in and above the boundary layer of a mountaintop site: identification of reactive trace gases and comparison with OH reactivity, Atmos. Chem. Phys., 18, 1204512059, https://doi.org/10.5194/acp-18-12045-2018, 2018 b.

Liebmann, J., Sobanski, N., Schuladen, J., Karu, E., Hellén, H., Hakola, H., Zha, Q., Ehn, M., Riva, M., Heikkinen, L., Williams, J., Fischer, H., Lelieveld, J., and Crowley, J. N.: Alkyl nitrates in the boreal forest: formation via the $\mathrm{NO}_{3-}^{-}, \mathrm{OH}-$ and $\mathrm{O}_{3}$-induced oxidation of biogenic volatile organic compounds and ambient lifetimes, Atmos. Chem. Phys., 19, 10391-10403, https://doi.org/10.5194/acp-19-10391-2019, 2019.

Mellouki, A. and Mu, Y.: On the atmospheric degradation of pyruvic acid in the gas phase, J. Photoch. Photobio. A, 157, 295-300, https://doi.org/10.1016/S1010-6030(03)00070-4, 2003.

Millet, D. B., Guenther, A., Siegel, D. A., Nelson, N. B., Singh, H. B., de Gouw, J. A., Warneke, C., Williams, J., Eerdekens, G., Sinha, V., Karl, T., Flocke, F., Apel, E., Riemer, D. D., Palmer, P. I., and Barkley, M.: Global atmospheric budget of acetaldehyde: 3-D model analysis and constraints from in-situ and satellite observations, Atmos. Chem. Phys., 10, 3405-3425, https://doi.org/10.5194/acp-10-3405-2010, 2010.
Millet, D. B., Baasandorj, M., Farmer, D. K., Thornton, J. A., Baumann, K., Brophy, P., Chaliyakunnel, S., de Gouw, J. A., Graus, M., Hu, L., Koss, A., Lee, B. H., Lopez-Hilfiker, F. D., Neuman, J. A., Paulot, F., Peischl, J., Pollack, I. B., Ryerson, T. B., Warneke, C., Williams, B. J., and Xu, J.: A large and ubiquitous source of atmospheric formic acid, Atmos. Chem. Phys., 15, 6283-6304, https://doi.org/10.5194/acp-15-6283-2015, 2015.

Noodleman, L.: Valence bond description of anti-ferromagnetic coupling in transition-metal dimers, J. Chem. Phys., 74, 57375743, 1981.

Olivella, S., Bofill, J. M., and Solé, A.: Ab Initio Calculations on the Mechanism of the Oxidation of the Hydroxymethyl Radical by Molecular Oxygen in the Gas Phase: A Significant Reaction for Environmental Science, Chemistry, 7, 3377-3386, https://doi.org/10.1002/1521-3765(20010803)7:15<3377::AIDCHEM3377>3.0.CO;2-8, 2001.

Paulot, F., Crounse, J. D., Kjaergaard, H. G., Kroll, J. H., Seinfeld, J. H., and Wennberg, P. O.: Isoprene photooxidation: new insights into the production of acids and organic nitrates, Atmos. Chem. Phys., 9, 1479-1501, https://doi.org/10.5194/acp-9-14792009, 2009.

Perring, A. E., Pusede, S. E., and Cohen, R. C.: An observational perspective on the atmospheric impacts of alkyl and multifunctional nitrates on ozone and secondary organic aerosol, Chem. Rev., 113, 5848-5870, https://doi.org/10.1021/cr300520x, 2013.

Petäjä, T., Mauldin, III, R. L., Kosciuch, E., McGrath, J., Nieminen, T., Paasonen, P., Boy, M., Adamov, A., Kotiaho, T., and Kulmala, M.: Sulfuric acid and $\mathrm{OH}$ concentrations in a boreal forest site, Atmos. Chem. Phys., 9, 7435-7448, https://doi.org/10.5194/acp9-7435-2009, 2009.

Praplan, A. P., Hegyi-Gaeggeler, K., Barmet, P., Pfaffenberger, L., Dommen, J., and Baltensperger, U.: Online measurements of water-soluble organic acids in the gas and aerosol phase from the photooxidation of 1,3,5-trimethylbenzene, Atmos. Chem. Phys., 14, 8665-8677, https://doi.org/10.5194/acp-148665-2014, 2014.

Purvis, G. D. and Bartlett, R. J.: A full coupled-cluster singles and doubles model - the inclusion of disconnected triples, J. Chem. Phys., 76, 1910-1918, https://doi.org/10.1063/1.443164, 1982.

Raber, W. H. and Moortgat, G. K.: Photooxidation of selected carbonyl compounds in air: methyl ethyl ketone, methyl vinyl ketone, methacrolein and methylglyoxal, in: Progress and problems in atmospheric chemistry, edited by: Barker, J. R., World Scientific Publishing, Singapore, 318-373, 1995.

Reed Harris, A. E., Doussin, J. F., Carpenter, B. K., and Vaida, V.: Gas-Phase Photolysis of Pyruvic Acid: The Effect of Pressure on Reaction Rates and Products, J. Phys. Chem. A, 120, 10123 10133, https://doi.org/10.1021/acs.jpca.6b09058, 2016.

Reed Harris, A. E., Cazaunau, M., Gratien, A., Pangui, E., Doussin, J.-F., and Vaida, V.: Atmospheric Simulation Chamber Studies of the Gas-Phase Photolysis of Pyruvic Acid, J. Phys. Chem. A, 121, 8348-8358, https://doi.org/10.1021/acs.jpca.7b05139, 2017a.

Reed Harris, A. E., Cazaunau, M., Gratien, A., Pangui, E., Doussin, J. F., and Vaida, V.: Atmospheric Simulation Chamber Studies of the Gas-Phase Photolysis of Pyruvic Acid, J. Phys. Chem. A, 121, 8348-8358, https://doi.org/10.1021/acs.jpca.7b05139, 2017 b. 
Rinne, J., Hakola, H., Laurila, T., and Rannik, Ü.: Canopy scale monoterpene emissions of Pinus sylvestris dominated forests, Atmos. Environ., 34, 1099-1107, https://doi.org/10.1016/S13522310(99)00335-0, 2000.

Roberts, J. M., Flocke, F., Chen, G., de Gouw, J., Holloway, J. S., Hübler, G., Neuman, J. A., Nicks Jr., D. K., Nowak, J. B., Parrish, D. D., Ryerson, T. B., Sueper, D. T., Warneke, C., and Fehsenfeld, F. C.: Measurement of peroxycarboxylic nitric anhydrides (PANs) during the ITCT 2K2 aircraft intensive experiment, J. Geophys. Res.-Atmos., 109, D23S21, https://doi.org/10.1029/2004jd004960, 2004.

Roiger, A., Aufmhoff, H., Stock, P., Arnold, F., and Schlager, H.: An aircraft-borne chemical ionization - ion trap mass spectrometer (CI-ITMS) for fast PAN and PPN measurements, Atmos. Meas. Tech., 4, 173-188, https://doi.org/10.5194/amt-4173-2011, 2011.

Samanta, B. R., Fernando, R., Rösch, D., Reisler, H., and Osborn, D. L.: Primary photodissociation mechanisms of pyruvic acid on S1: observation of methylhydroxycarbene and its chemical reaction in the gas phase, Phys. Chem. Chem. Phys., 23, 4107-4119, https://doi.org/10.1039/D0CP06424F, 2021.

Sander, R., Baumgaertner, A., Cabrera-Perez, D., Frank, F., Gromov, S., Grooß, J.-U., Harder, H., Huijnen, V., Jöckel, P., Karydis, V. A., Niemeyer, K. E., Pozzer, A., Riede, H., Schultz, M. G., Taraborrelli, D., and Tauer, S.: The community atmospheric chemistry box model CAABA/MECCA-4.0, Geosci. Model Dev., 12, 1365-1385, https://doi.org/10.5194/gmd-121365-2019, 2019.

Schreiner, P. R., Reisenauer, H. P., Ley, D., Gerbig, D., Wu, C. H., and Allen, W. D.: Methylhydroxycarbene: Tunneling control of a chemical reaction, Science, 332, 1300-1303, https://doi.org/10.1126/science.1203761, 2011.

Shepson, P. B., Bottenheim, J. W., Hastie, D. R., and Venkatram, A.: Determination of the relative ozone and PAN deposition velocities at night, Geophys. Res. Lett., 19, 1121-1124, https://doi.org/10.1029/92g101118, 1992a.

Shepson, P. B., Hastie, D. R., So, K. W., and Schiff, H. I.: Relationships between PAN, PPN and $\mathrm{O}_{3}$ at urban and rural sites in ontario, Atmos. Environ. A-Gen., 26, 1259-1270, https://doi.org/10.1016/0960-1686(92)90387-z, 1992b.

Sobanski, N., Schuladen, J., Schuster, G., Lelieveld, J., and Crowley, J. N.: A five-channel cavity ring-down spectrometer for the detection of $\mathrm{NO}_{2}, \mathrm{NO}_{3}, \mathrm{~N}_{2} \mathrm{O}_{5}$, total peroxy nitrates and total alkyl nitrates, Atmos. Meas. Tech., 9, 5103-5118, https://doi.org/10.5194/amt-9-5103-2016, 2016.

Stefan, M. I. and Bolton, J. R.: Reinvestigation of the acetone degradation mechanism in dilute aqueous solution by the $\mathrm{UV} / \mathrm{H}_{2} \mathrm{O}_{2}$ process, Environ. Sci. Technol., 33, 870-873, https://doi.org/10.1021/es9808548, 1999.

Talbot, R., Andreae, M., Berresheim, H., Jacob, D. J., and Beecher, K.: Sources and sinks of formic, acetic, and pyruvic acids over Central Amazonia: 2. Wet season, J. Geophys. Res.-Atmos., 95, 16799-16811, https://doi.org/10.1029/JD095iD10p16799, 1990.

Vereecken, L. and Peeters, J.: The 1,5-H-shift in 1-butoxy: A case study in the rigorous implementation of transition state theory for a multirotamer system, J. Chem. Phys., 119, 5159-5170, https://doi.org/10.1063/1.1597479, 2003.
Vereecken, L., Pierloot, K., and Peeters, J.: B3LYP-DFT characterization of the potential energy surface of the $\mathrm{CH}(X 2 \Pi)+\mathrm{C}_{2} \mathrm{H}_{2}$ reaction, J. Chem. Phys., 108, 1068-1080, https://doi.org/10.1063/1.475345, 1998.

Vesley, G. F. and Leermakers, P. A.: Photochemistry of alpha-keto acids + alpha-keto esters. 3. Photolysis of pyruvic acid in vapor phase, J. Phys. Chem., 68, 2364-2366, https://doi.org/10.1021/j100790a507, 1964.

Walker, D.: Pyruvate carboxylation and plant metabolism, Biol. Rev., 37, 215-254, https://doi.org/10.1111/j.1469185X.1962.tb01611.x, 1962.

Wang, N., Edtbauer, A., Stönner, C., Pozzer, A., Bourtsoukidis, E., Ernle, L., Dienhart, D., Hottmann, B., Fischer, H., Schuladen, J., Crowley, J. N., Paris, J.-D., Lelieveld, J., and Williams, J.: Measurements of carbonyl compounds around the Arabian Peninsula: overview and model comparison, Atmos. Chem. Phys., 20, 10807-10829, https://doi.org/10.5194/acp-20-108072020, 2020.

Wang, S. Y., Hornbrook, R. S., Hills, A., Emmons, L. K., Tilmes, S., Lamarque, J. F., Jimenez, J. L., Campuzano-Jost, P., Nault, E. A., Crounse, J. D., Wennberg, P. O., Kim, M., Allen, H., Ryerson, T. B., Thompson, C. R., Peischl, J., Moore, F., Nance, D., Hall, B., Elkins, J., Tanner, D., Huey, L. G., Hall, S. R., Ullmann, K., Orlando, J. J., Tyndall, G. S., Flocke, F. M., Ray, E., Hanisco, T. F., Wolfe, G. M., St Clair, J., Commane, R., Daube, B., Barletta, B., Blake, D. R., Weinzierl, B., Dollner, M., Conley, A., Vitt, F., Wofsy, S. C., Riemer, D. D., and Apel, E. C.: Atmospheric acetaldehyde: importance of air-sea exchange and a missing source in the remote troposphere, Geophys. Res. Lett., 46, 5601-5613, https://doi.org/10.1029/2019gl082034, 2019.

Williams, J., Crowley, J., Fischer, H., Harder, H., Martinez, M., Petäjä, T., Rinne, J., Bäck, J., Boy, M., Dal Maso, M., Hakala, J., Kajos, M., Keronen, P., Rantala, P., Aalto, J., Aaltonen, H., Paatero, J., Vesala, T., Hakola, H., Levula, J., Pohja, T., Herrmann, F., Auld, J., Mesarchaki, E., Song, W., Yassaa, N., Nölscher, A., Johnson, A. M., Custer, T., Sinha, V., Thieser, J., Pouvesle, N., Taraborrelli, D., Tang, M. J., Bozem, H., Hosaynali-Beygi, Z., Axinte, R., Oswald, R., Novelli, A., Kubistin, D., Hens, K., Javed, U., Trawny, K., Breitenberger, C., Hidalgo, P. J., Ebben, C. J., Geiger, F. M., Corrigan, A. L., Russell, L. M., Ouwersloot, H. G., Vilà-Guerau de Arellano, J., Ganzeveld, L., Vogel, A., Beck, M., Bayerle, A., Kampf, C. J., Bertelmann, M., Köllner, F., Hoffmann, T., Valverde, J., González, D., Riekkola, M.-L., Kulmala, M., and Lelieveld, J.: The summertime Boreal forest field measurement intensive (HUMPPA-COPEC-2010): an overview of meteorological and chemical influences, Atmos. Chem. Phys., 11, 10599-10618, https://doi.org/10.5194/acp-11-10599-2011, 2011.

Yamamoto, S. and Back, R. A.: The photolysis and thermaldecomposition of pyruvic-acid in the gas-phase, Can. J. Chem., 63, 549-554, https://doi.org/10.1139/v85-089, 1985.

Zhao, Y. and Truhlar, D. G.: The M06 suite of density functionals for main group thermochemistry, thermochemical kinetics, noncovalent interactions, excited states, and transition elements: two new functionals and systematic testing of four M06-class functionals and 12 other functionals, Theor. Chem. Account., 120, 215-241, https://doi.org/10.1007/s00214-007-0310-x, 2008. 